\title{
LncRNAs as Regulators of Autophagy and Drug Resistance in Colorectal Cancer
}

\author{
Mercedes Bermúdez ${ }^{1}$, Maribel Aguilar-Medina ${ }^{1}$, Erik Lizárraga-Verdugo ${ }^{1}$, \\ Mariana Avendaño-Félix ${ }^{1}$, Erika Silva-Benítez ${ }^{2}$, Cesar López-Camarillo ${ }^{3}$ and \\ Rosalío Ramos-Payán ${ }^{1 *}$ \\ ${ }^{1}$ Facultad de Ciencias Químico Biológicas, Universidad Autónoma de Sinaloa, Culiacán, Mexico, ${ }^{2}$ Facultad de Odontología, \\ Universidad Autónoma de Sinaloa, Culiacán, Mexico, ${ }^{3}$ Posgrado en Ciencias Genómicas, Universidad Autónoma de la \\ Ciudad de México, Mexico City, Mexico
}

OPEN ACCESS

Edited by:

Carlos Pérez-Plasencia,

National Autonomous University of

Mexico, Mexico

Reviewed by:

Nadia Judith Jacobo-Herrera,

Instituto Nacional de Ciencias

Médicas y Nutrición Salvador Zubirán

(INCMNSZ), Mexico

Paul Dent,

Virginia Commonwealth University,

United States

Khalid Omer Alfarouk,

Alfarouk Biomedical Research LLC,

United States

*Correspondence:

Rosalío Ramos-Payán

rosaliorp@uas.edu.mx

Specialty section:

This article was submitted to

Cancer Metabolism,

a section of the journal

Frontiers in Oncology

Received: 31 July 2019 Accepted: 19 September 2019

Published: 02 October 2019

Citation:

Bermúdez M, Aguilar-Medina M, Lizárraga-Verdugo $E$, Avendaño-Félix M, Silva-Benítez E,

López-Camarillo $C$ and

Ramos-Payán R (2019) LncRNAs as

Regulators of Autophagy and Drug

Resistance in Colorectal Cancer.

Front. Oncol. 9:1008

doi: 10.3389/fonc. 2019.01008
Colorectal cancer (CRC) is a common malignancy with 1. 8 million cases in 2018 . Autophagy helps to maintain an adequate cancer microenvironment in order to provide nutritional supplement under adverse conditions such as starvation and hypoxia. Additionally, most of the cases of CRC are unresponsive to chemotherapy, representing a significant challenge for cancer therapy. Recently, autophagy induced by therapy has been shown as a unique mechanism of resistance to anticancer drugs. In this regard, long non-coding RNAs (IncRNAs) analysis are important for cancer detection, progression, diagnosis, therapy response, and prognostic values. With increasing development of quantitative detection techniques, IncRNAs derived from patients' non-invasive samples (i.e., blood, stools, and urine) has become into a novel approach in precision oncology. Tumorspecific GAS5, HOTAIR, H19, and MALAT are novels $\mathrm{CRC}$ related IncRNAs detected in patients. Nonetheless, the effect and mechanism of IncRNAs in cancer autophagy and chemoresistance have not been extensively characterized. Chemoresistance and autophagy are relevant for cancer treatment and IncRNAs play a pivotal role in resistance acquisition for several drugs. LncRNAs such as HAGLROS, KCNQ1OT1, and H19 are examples of IncRNAs related to chemoresistance leaded by autophagy. Finally, clinical implications of IncRNAs in CRC are relevant, since they have been associated with tumor differentiation, tumor size, histological grade, histological types, Dukes staging, degree of differentiation, lymph node metastasis, distant metastasis, recurrent free survival, and overall survival (OS).

Keywords: IncRNA, colorectal cancer, autophagy, chemoresistance, drug resistance, macroautophagy

\section{INTRODUCTION}

Cancer is one of the most deathly illness worldwide with an estimated 9.6 million deaths in 2018 (1). One of the most common is colorectal cancer (CRC) with 1.8 million cases and 862,000 deaths only during the last year (1). Development of CRC involves different genetic and epigenetic changes. Most cases are sporadic and show a slow development through the time, advancing from adenoma to carcinoma (2). Even though there are important progress in treatment and molecular mechanisms involved in CRC, the OS rate still remains relatively low $(3,4)$. 
Chemotherapy has been widely used for cancer treatment, for instance, the fluoropyrimidine 5-fluorouracil (5-FU) is a first selection anticancer drugs for CRC treatment (5). Besides, new drugs such as cetuximab and panitumumab have been incorporated into clinical practice (6). Nevertheless, drug resistance acquisition is one of the main issues in effective chemotherapy (7). This due to different factors as Pharmacokinetic Resistance, that includes since absorption until, distribution, metabolism, and the excretion of drugs. In addition, the evolutionary resistance, a process that occurs in the tumor where the cells acquire the ability to survive chemotherapy, this through expression of different proteins, such as P-glycoprotein 1 (P-gp) also known as, multidrug resistance protein 1 (MDR1). Besides the physics of the tumor site is involved in chemotherapy resistance such as, number and morphology of vessels and blood viscosity, are important factors involved (8). Drug ineffectiveness could be the result from tumor-host interactions and a clear understanding of such an interaction will open new opportunities not only for the discovery of new drugs but also for new therapeutic strategies to overcome the development and evolution of resistance to cancer chemotherapy.

Autophagy is an important cellular response to stress or starvation and starts when organelles and proteins are sequestered in vesicles and delivered to lysosomes for degradation (9). New research revealed that autophagy has different functions in the development, maintenance, and tumor progression (10) and recently, autophagy induced by therapy has been shown as a new mechanism of resistance to chemotherapeutic drugs (11). Through carcinogenic process of CRC, autophagy could promote tumor survival or cancer cell death, and it depends on the tumor type, stage, and the metabolic setting (12).

Non-coding RNAs (ncRNAs) represent 99\% of total transcribed RNAs in the human genome, being the principal components of the human transcriptome (13). Recently, ncRNAs have shown to play key roles in important biological processes by interfering with gene expression in several cancer types $(14,15)$.

The best characterized of the "expanding universe" of ncRNAs are the $\sim 22$ nucleotide microRNAs (miRNAs) and the long noncoding RNAs (lncRNAs). The lncRNAs are classified as $>200$ nucleotides in length and are involved in a wide variety of molecular genetics and cellular processes in many aspects of gene regulation, including imprinting, epigenetic modulation, transcription, mRNA splicing, and tracking between the nucleus and cytoplasm (15-18). Moreover, lncRNAs are involved in variety biological processes such as, proliferation, differentiation, apoptosis, invasion, and metastasis.

Recently, lncRNAs have been implicated in tumor-drug resistance and autophagy in different types of cancer including CRC $(16,19-22)$. Therefore, the aim of this review is to compile the current knowledge about lncRNAs and their implication on chemoresistance and autophagy in CRC. To this end, we searched on PubMed, PMC, Web of Science, Google scholar, and EMBASE up to July 2019 for pertinent articles using the keywords as follows: (lncRNA or long non-coding RNA) and (CRC or colorectal cancer) and (autophagy or autophagia) and (chemoresistance or drug resistance). The titles and abstracts were screened, and we acquired the relevant full-text manuscripts for perusal.

\section{LONG NON-CODING RNAS}

\section{Biogenesis, Classification, and Function}

LncRNAs include different types of RNA polymerase II (Pol II)transcribed molecules with sizes over $200 \mathrm{nt}$ in length. It has been reported an estimated abundance of 5,400 to more than 10,000 lncRNAs transcripts in humans $(23,24)$. All mammalian lncRNAs share a few structural, functional, or mechanistic characteristics among them. They often harbor a poly-A tail and can be spliced, similar to mRNAs (25). Besides, they regulate gene expression at transcriptional and post-transcriptional levels in multiple biological processes and cellular contexts (26-28).

Spurlock et al., classified LncRNAs based on their structural origin context (Figure 1). Overlapping when a protein-coding genes is included in the intron of a lncRNA $(29,30)$, divergent when the lncRNA and neighboring protein coding gene are transcribed on opposite strands (31), intronic when the whole sequence of the lncRNA belongs to the intron of a protein-coding gene (32), intergenic when a lncRNA sequence belongs to two genes as a distinct unit (33), and sense (34) or antisense (35) when the lncRNA is located between one or more exons of another transcript on the same sense or antisense strand (36-38). Lastly, enhancer RNAs can be transcribed in one or two senses, 1DeRNAs and 2D-eRNAs, respectively, at genomic transcriptional enhancers, frequently very close to protein-coding genes (39).

It has been shown that lncRNAs functions depend on their subcellular location (26). There is evidence in human cell lines using single molecule RNA fluorescence in situ-hybridization that revealed a wide range of subcellular localization patterns, including nucleus, cytoplasm and both (40). Nevertheless, it is most common to catalog lncRNAs based on similar action mechanisms (25) (Figure 2).

Some lncRNAs have a very important role in nuclear structure, since they help to the structure of nuclear speckles, paraspeckles, and interchromatin granules (41). Another nuclear lncRNAs are able to regulate gene expression by epigenetic mechanisms and recruiting chromatin-modification factors in order to switch-on or switch-off different loci (42). Besides, there are other types of stable lncRNAs, such as competing endogenous RNAs (ceRNAs) and circular RNAs, which are accumulated in the cell acting as decoys or sponges for miRNAs modulating gene expression (43).

LncRNAs also has an important role in transcription since they help in assembling transcriptional activators and repressors for modulating the activation of transcription (44). Besides, lncRNAs are able to modulate gene expression posttranscriptionally by interfering with RNA-binding proteins to impact splicing and translation and by modulating the translation and stability of partially complementary mRNAs $(45,46)$. In addition, some lncRNAs function post-transductionally in order to regulate protein turnover to enhance ubiquitination (47).

\section{Detection Methods}

The lncRNAs importance in cancer characteristics such as progression, autophagy, and chemotherapy resistance has been 


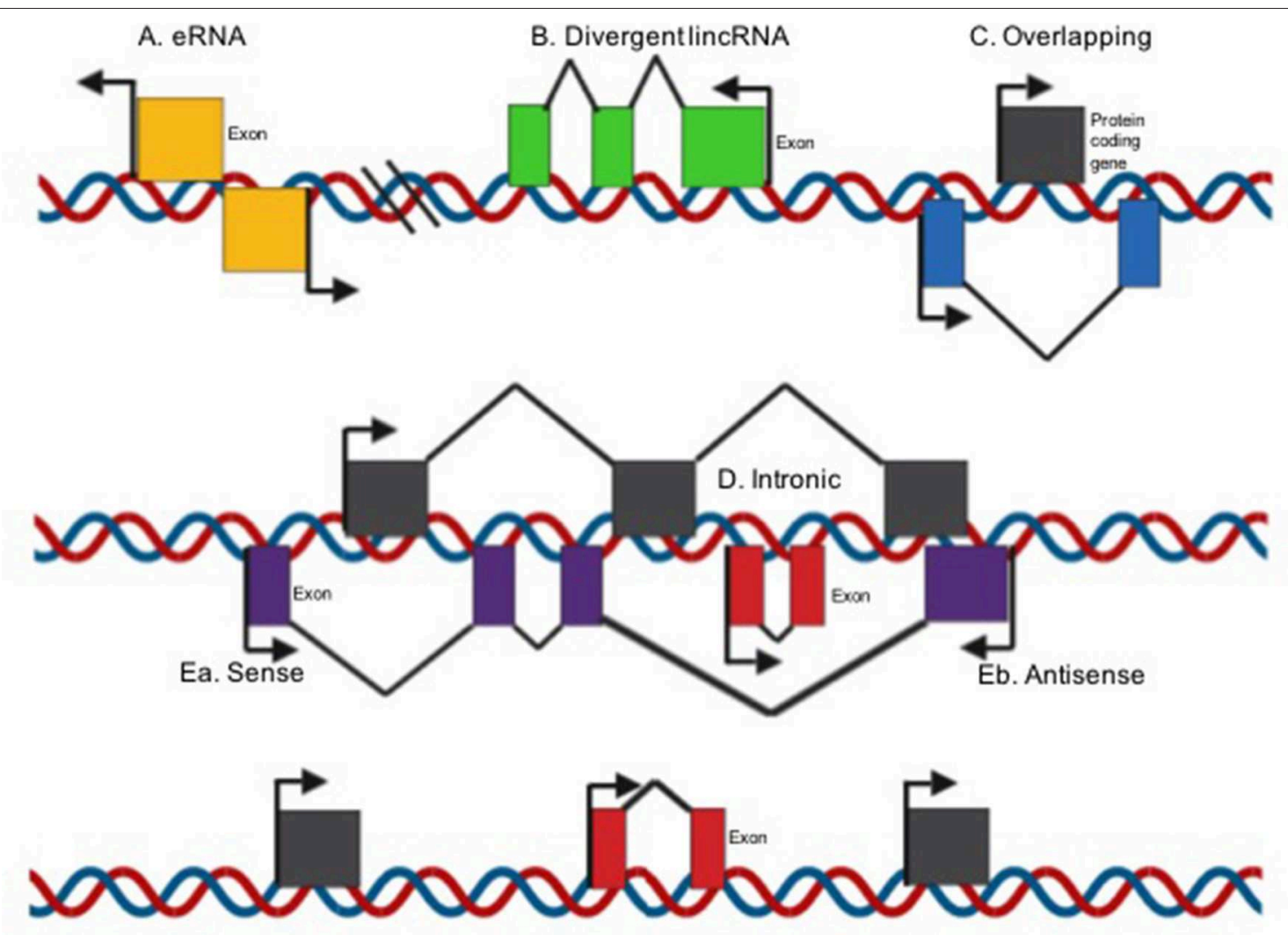

F. Intergenic

FIGURE 1 | LncRNA classification on their structural origin context [modified image from Spurlock et al. (29)]. (A) Enhancer RNAs can be transcribed in one or two senses 1D-eRNAs and 2D-eRNAs, respectively, at genomic transcriptional enhancers, frequently in close proximity to protein-coding genes; (B) Divergent when the lincRNA and nearby protein coding gene are transcribed on opposite strands; (C) overlapping when a protein-coding genes is included in the intron of a IncRNA; (D) Intronic when the whole sequence of the IncRNA belongs to the intron of a protein-coding gene; Ea. Sense or (E) antisense if the IncRNA is located between one or more exons of another transcript on the same sense or antisense strand; (F) intergenic when a IncRNA sequence belongs to two genes as a distinct unit.

established thanks to more advanced detection technologies. The main two methods for lncRNAs detection are microarrays and RNA sequencing (RNA-seq), Microarrays contain probe sequences that match with lncRNAs (48). Whereas, RNAseq provides comprehensive coverage of whole transcriptomes compared to microarrays. Due to unbiased genome-wide screening, it is possible to exclude ribosomal RNAs (rRNAs) from total RNA to enhance it, including protein-coding genes and lncRNAs. Besides, it is possible to enrich mRNAs using oligo-dT beads with poly A tails, giving as a result the detection of proteincoding genes and lncRNAs with poly A tails that are nearly $60 \%$ of total lncRNAs $(49,50)$.

Since lncRNAs has been described as biomarkers in several types of cancer, non-invasive detection methods have been developed (Table 1) for early diagnostic, evolution, and poor prognosis of cancer (62). Thus, there are several carcinomas that can be detected by specific serum circulating lncRNAs (Table 1) (63). Moreover, lncRNAs are detectable in urine and may serve as biomarker predictor in T-cell mediated kidney transplant rejection as well as bladder cancer tumor-stage $(64,65)$. In addition, US Food and Drug administration (FDA) has recently approved PCA3 lncRNA as a biomarker for prostate cancer in urine $(66,67)$ showing better sensitivity and specificity than Prostate-specific antigen (PSA) blood test (68). Whole saliva also represents a source for cancer biomarkers by lncRNAs detection, given this, saliva contains certain lncRNAs that can be used as biomarkers for oral squamous cell carcinoma diagnosis such as HOTAIR, which presence in saliva samples is correlated with high levels in metastatic tissues (69).

\section{LNCRNAS IN COLORECTAL CANCER}

LncRNAs play key roles regulating gene expression during cell development and differentiation, regulating or maintaining cellular homeostasis (70, 71). Abnormal expression of lncRNAs has been reported in numerous cancer types such as; hematopoietic, urologic, lung, liver, breast, ovarian, and colorectal (72-79). Alterations of these molecules are studied in CRC in order to obtain clinical biomarkers for diagnostic, prognostic, and therapeutic applications (80, 81). Multiple lncRNAs have been related with CRC as important clinical and 


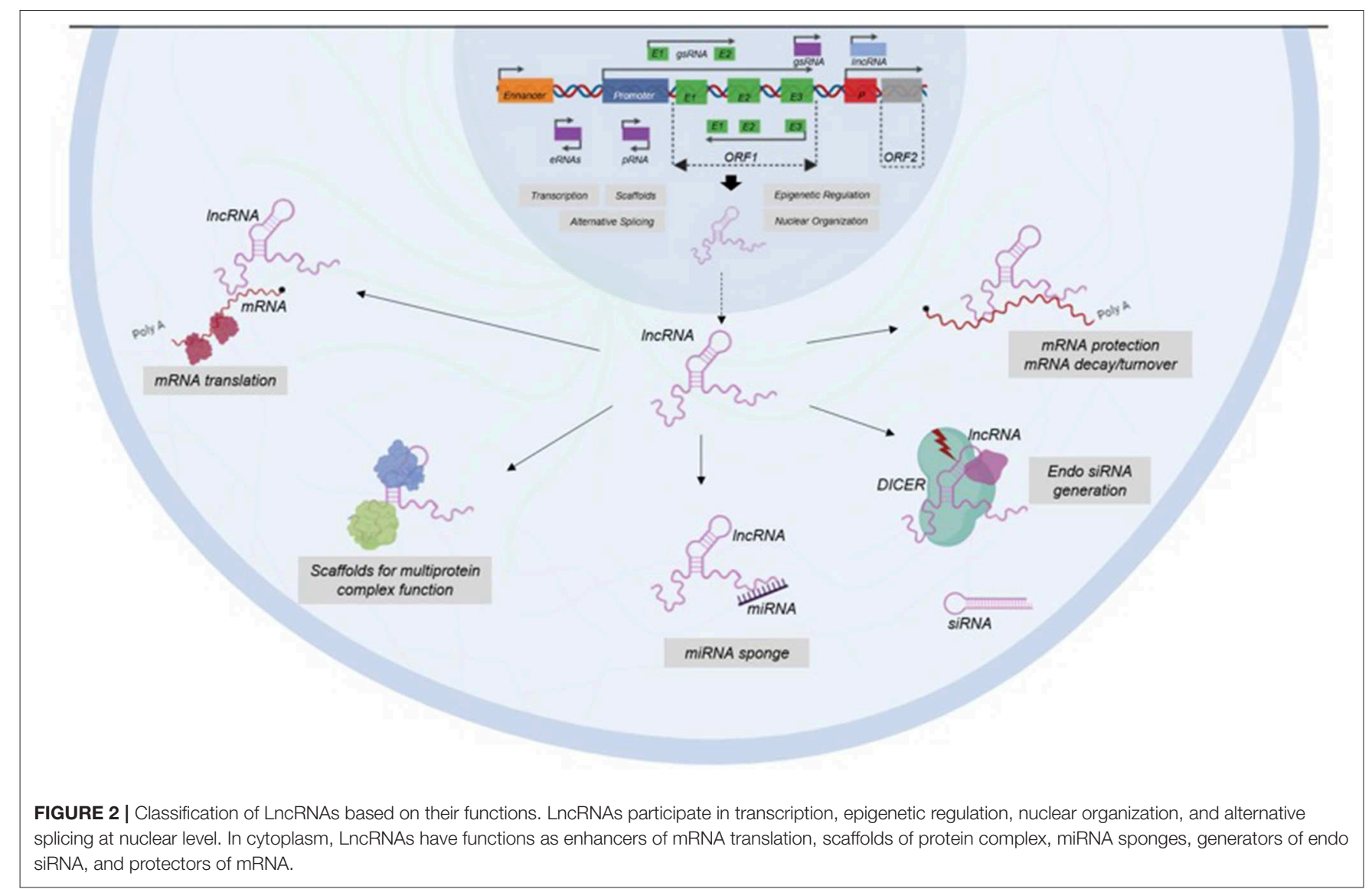

TABLE 1 | Circulating IncRNAs detected in serum in different types of cancer.

\begin{tabular}{llc}
\hline LncRNA & $\begin{array}{l}\text { Associated } \\
\text { cancer }\end{array}$ & References \\
\hline $\begin{array}{l}\text { RP11-04K16.1, LOC_012542, } \\
\text { PVT1 }\end{array}$ & $\begin{array}{l}\text { Cervical } \\
\text { cancer } \\
\text { LNHG }\end{array}$ & $(51,52)$ \\
H19 & $\begin{array}{l}\text { Multiple } \\
\text { myeloma }\end{array}$ & $(53)$ \\
PCA3, BCAR4, CRNDE-h, & Colorectal & $(54)$ \\
LNCV6_116109, LNCV6_98390, & & $(55-58)$ \\
LNCV6_38772, LNCV_108266, & & \\
LNCV6_84003, LNCV6_98602, & & \\
u50535 & & \\
H19, IncUEGC1 & Gastric \\
LINC00161 & Hepatocellular \\
& carcinoma & $(59,60)$ \\
\hline
\end{tabular}

mechanistic molecules (Table 2) and there are some lncRNA that are strongly associated to CRC and presented below.

In this regard, the growth arrest-specific transcript 5 (GAS5), is located at 1q25, with a length of $630 \mathrm{nt}$ (95). GAS5 is upregulated during growth arrest induced by the absence of growth factors or serum starvation. It has been shown that GAS5 binds to the DNA-binding domain of the glucocorticoid receptor (GR) and acts as a decoy glucocorticoid response element
(GRE), therefore it can compete with DNA GREs for binding to the GR (95). This lncRNA is able to inhibit cell proliferation and promote apoptosis, by acting as tumor suppressor (96). Nowadays, researches demonstrate that GAS5 is downregulated in several cancer cells such as, breast cancer, prostate cancer, and renal carcinoma (97-99).

In human CRC tumor tissues, Gas5 has been found downregulated and it is correlated with tumor size, TNM staging, lymph node metastasis, low histological grade and less OS (100104). Besides, overexpression of GAS5 shows that could inhibit cell proliferation in vitro and in vivo (102), prevent migration and invasion $(100,105)$, and promotes apoptosis $(100,101,103)$ through inhibition of mRNA expression of Akt and Erk and protein expression of $\mathrm{p}$-Akt and p-Erk, giving as a result A phoCasp9 protein expression and inhibition of pho-Casp3 protein expression (100). Another mechanism of GAS5 to inhibit the apoptosis could be through the GAS5/miR-182-5p/FOXO3a axis, since GAS5 acts as ceRNA of miR-18-5p, which regulates a pro-apoptotic transcription factor named FOXO3a, and target directly the PI3K-AKT signaling pathway (101).

In the case of HOTAIR (Homeobox Transcript Antisense Intergenic RNA), a $2.2 \mathrm{~kb}$ lncRNA, is transcribed from the mammalian HOXC gene cluster located in 12q13.13 (106). It participates in epigenetic regulation of gene transcription and interacts on its $5^{\prime}$ end with Polycomb repressive complex 2 in order to remodel chromatin and guarantee silencing of HOX 
TABLE 2 | Important IncRNAs involved in CRC.

\begin{tabular}{|c|c|c|c|}
\hline IncRNA & $\begin{array}{l}\text { Status of } \\
\text { expression }\end{array}$ & Participation in CRC & References \\
\hline XLOC_010588 & Upregulated & $\begin{array}{l}\text { Associated with metastasis, poor prognosis, invasion, migration, and the progression of CRC } \\
\text { via EMT pathway }\end{array}$ & $(82)$ \\
\hline FTX & Upregulated & $\begin{array}{l}\text { Tumor diameter, TNM stage, the lymph node, and distant metastasis and poor prognosis of } \\
\text { patients with CRC. In vitro, promotes CRC cell proliferation, migration, invasion, and interacts } \\
\text { with miR-215 and vimentin }\end{array}$ & (83) \\
\hline BLACAT1 & Upregulated & Proliferation, both in vitro and in vivo, and have a role in G1/G0 arrest by binding to EZH2 & (84) \\
\hline Inc-CRCMSL & Downregulated & $\begin{array}{l}\text { Overexpression restricts tumor growth and metastasis in vivo and in vitro and the silencing } \\
\text { accelerates CRC cell proliferation and migration. Also, mediates suppression EMT process by } \\
\text { HMGB2 }\end{array}$ & (85) \\
\hline DANCR & Upregulated & $\begin{array}{l}\text { Promotes proliferation and metastasis in CRC. DANCR promotes HSP27 expression and its } \\
\text { mediation of proliferation/metastasis via miR-577 sponging. In vivo, DANCR promotes CRC } \\
\text { tumor growth and liver metastasis }\end{array}$ & $(86)$ \\
\hline Inc-DILC & Upregulated & $\begin{array}{l}\text { Inhibits the growth and metastasis of CRC cells. Knockdown, facilitates the proliferation and } \\
\text { metastasis of CRC cells. Lnc-DILC is a CRC suppressor by inactivating IL-6/STAT3 signaling }\end{array}$ & $(87)$ \\
\hline kcna3 & Downregulated & $\begin{array}{l}\text { Higher TNM grade and the higher occurrence rate of lymphatic metastasis and distant } \\
\text { metastasis, and shorter OS. Overexpression, inhibits proliferation, migration and invasion and } \\
\text { induces cell apoptosis in vitro, and represses CRC tumor growth in vivo. Also, exerts a } \\
\text { tumor-inhibit role in CRC progression through down-regulating YAP1 expression }\end{array}$ & (88) \\
\hline Loc554202 & Downregulated & $\begin{array}{l}\text { Associated with advanced TNM and a larger tumor size. The overexpression decreases the cell } \\
\text { proliferation and induces apoptosis in vitro and delay tumorigenesis in vivo. Regulates cell } \\
\text { apoptosis through the activation of specific caspase cleavage cascades }\end{array}$ & (89) \\
\hline MAPKAPK5- AS1 & Upregulated & $\begin{array}{l}\text { Greater tumor size and advanced TNM in CRC patients. Knockdown, inhibits proliferation and } \\
\text { causes apoptosis in CRC cells. Also, p21 is a target of MAPKAPK5- AS1 }\end{array}$ & $(90)$ \\
\hline ZNFX1-AS1 & Upregulated & $\begin{array}{l}\text { Associated with aggressive tumor phenotype and poor prognosis in CRC. Knockdown inhibits } \\
\text { cell proliferation and invasion in vitro, and tumorigenesis and metastasis in vivo. ZNFX1-AS1 } \\
\text { works as a ceRNA for miR-144, inhibiting to EZH2 }\end{array}$ & (91) \\
\hline u50535 & Upregulated & Activates CCL20 signaling to promote cell proliferation and migration in CRC & $(58)$ \\
\hline DUXAP10 & Upregulated & $\begin{array}{l}\text { Positively correlated with advanced pathological stages, larger tumor sizes, and lymph node } \\
\text { metastasis. Knockdown inhibits cell proliferation, induces cell apoptosis and increase G0/G1 } \\
\text { cells. DUXAP10 silencing inhibits tumor growth in vivo, also promotes CRC cell growth and } \\
\text { reduces cell apoptosis through silencing the expression of p21 and PTEN by binding LSD1 }\end{array}$ & $(92)$ \\
\hline NNT-AS1 & Upregulated & $\begin{array}{l}\text { Correlated with lymph node metastasis, TNM stage, vessel invasion and differentiation, Also, is } \\
\text { an independent predictor of OS and progression free survival. Knockdown, inhibits CRC cell } \\
\text { proliferation, migration and invasion in vitro and suppress tumor growth and metastasis in nude } \\
\text { mice by NNT-AS1-mediated activating of MAPK/Erk signaling pathway and EMT }\end{array}$ & (93) \\
\hline $91 \mathrm{H}$ & Upregulated & $\begin{array}{l}\text { Associated with distant metastasis and poor prognosis in patients with CRC. Also, is an } \\
\text { independent prognostic indicator and of distant metastasis. In vitro, knockdown of } 91 \mathrm{H} \text { inhibits } \\
\text { the proliferation, migration, and invasiveness of CRC cells }\end{array}$ & (94) \\
\hline
\end{tabular}

genes during embryonic development. On $3^{\prime}$ end HOTAIR interacts with histone demethylase (107). Evidence shows that HOTAIR exhibits an oncogenic role in renal, breast, gastric, lung, and ovarian cancer (108-112).

HOTAIR is overexpressed at high levels in CRC (113-116) and some studies show that HOTAIR is only overexpressed in right (proximal) CRCs samples (117). This overregulation has been associated to lymph node and tumor node metastasis, distant metastases, Duke's staging, histological types, the degree of differentiation (113), and unfavorable prognosis $(114,118)$. In vitro, the inhibition of its expression shows decreased proliferation, invasion, and migration, as well as low cyclin E and CDK2 expression, increased apoptosis and p21 expression (113). Besides, HOTAIR promotes tumorigenesis and aggressiveness (114). This IncRNA directly harbors miR326 binding sites and regulates FUT6 expression, a specific fucosyl transferase. The HOTAIR/miR-326/FUT6 axis modifies a1, 3-fucosylation of CD44, which triggers PI3K/AKT/mTOR pathway mediating CRC malignancy (114). In addition, HOTAIR knockdown and miR-203a-3p upregulation in CRC cell lines produces inhibited $\mathrm{Wnt} / \beta$-catenin signaling, cell proliferation, and reduced chemoresistance (116).

The $\mathrm{H} 19$ gene is located on $11 \mathrm{p} 15$ and plays pivotal roles in embryonal development and growth regulation $(119,120)$. The H19 gene encodes for a processed $2.7 \mathrm{~kb}$ RNA (121). H19 is highly expressed from the onset of embryogenesis to fetal life in vital organs such as the fetal adrenal, liver, and placenta but is downregulated postnatal stages (122). Recent evidence shows that H19 is upregulated in several cancers as, esophageal cancer, hepatocellular carcinoma, ovarian cancer, bladder cancer, and breast cancer (123-127).

It has been demonstrated that $\mathrm{H} 19$ is upregulated in CRC tissues compared with adjacent noncancerous tissues $(9,128,129)$. Data from The Cancer Genome Atlas (TCGA) 
shows that $\mathrm{H} 19$ is the lncRNA with the most substantial correlation to CRC patient survival (130), serving as an independent predictor for OS and disease-free survival (DFS) (9, 131). Besides, this IncRNA has been related with poor prognosis (132).

Besides, miR-200a binds H19 and inhibits its expression, thus decreasing proliferation of CRC cells, also H19 regulates the expression and activity of $\beta$-catenin by competitive binding to miR-200a (128). In addition, depletion of H19 inhibits cell viability and induces growth arrest whereas overexpression of H19 upregulates a series of cell-cycle genes. Moreover, H19 binds to eIF4A3 resulting in an abnormal cell-cycle-regulatory genes expression (131).

H19 promotes invasion and metastasis in CRC through activation of RAS-MAPK signaling pathway (133) and its overexpression in MTX-resistant colorectal cell line HT-29 prove that is involved in Metrotexate (MTX) resistance via activating $\mathrm{Wnt} / \beta$-catenin signaling (134). The overexpression of H19 and miR-675 in CRC implies that both are important factors in the tumorigenesis of CRC since H19-derived miR-675, targets tumor suppressor RB (129).

Interestingly, mesenchymal-like cancer cells and primary CRC tissues show high expression of H19, whereas its stable expression accelerates tumor growth and enhances epithelial-mesenchymal transition (EMT) progression. Finally, H19 can function as ceRNA by antagonizing the functions of miR-138 and miR-200a, giving as a result the de-repression of Vimentin, ZEB1, and ZEB2 (135).

Finally, metastasis-associated lung adenocarcinoma transcript 1 (MALAT-1), is on $11 \mathrm{q} 13$ and transcribed from the nuclearenriched transcript 2 (NEAT2), which has been identified as a prognostic factor in patients with stage I lung cancer $(136,137)$. It has been reported that this lncRNA is expressed in mouse and normal human tissues $(137,138)$ and its overexpression have been demonstrated in many cancer types including lung, cervical, liver, bladder and sarcomas of uterus (139-144), and correlated to metastasis (137).

The MALAT1 levels are up-regulated in human primary CRC tissues (136), being 2.26 times higher than noncancerous tissues (145), serving as a negative prognostic marker in stage II/III CRC patients, since, these patients show a high hazard ratio (HR) for OS and DFS (145). Moreover, upregulation of MALAT1 has been found in CRC tissues with lymph node metastasis (136). In vitro, MALAT1 could promote CRC cell proliferation, invasion, and migration through up-regulating SOX9 and down-regulating miR-145. On the other hand, cell cycle and apoptosis can be suppressed by MALAT1/miR-145/SOX9 axis (146). Furthermore, MALAT1 regulates proliferation, migration, and promotes tumor growth and metastasis in nude mice (136), this regulation could be through SFPQ and AKAP9 as MALAT1 interact with SFPQ, hence releasing PTBP2 from the SFPQ/PTBP2 complex, facilitating cell proliferation and migration (147). AKAP-9 is overexpressed in CRC cells with metastatic potential and human primary CRC tissues with lymph node metastasis, and its knockdown blocks CRC cell proliferation, migration, and invasion mediated by MALAT1 (136).
Angiogenesis and the EMT to promote metastasis in CRC are enhanced by YAP1-induced MALAT1-miR126-5p axis since YAP1 forms a complex with $\beta$-catenin/TCF4 bound to the MALAT1 promoter, which can act as a sponge of miR-126$5 p$ to induce SLUG, VEGFA, and TWIST expression (148). miR-20b-5p-mimic and si-MALAT1 give as a result attenuated microsphere formation and self-renewal capability, reduces the proportion of CSCs, downregulating the expression of stemness markers as Oct4, Nanog, Sox2, and Notch1, and cellular metabolism such as GLUT1, LDHB, HK2, and PKM2 in HCT-116 cells in vitro. Additionally, the administration of either si-MALAT1 or miR-20b-5p-mimic in a xenograft model based on $\mathrm{BALB} / \mathrm{c}$ mice demonstrated that they can suppress tumorigenicity of HCT-116 cells in vivo (149).

As we reviewed above, HOTAIR, H19, and MALAT are overexpressed in CRC samples. Interestingly, HOTAIR and MALAT level expression are related to lymph node and tumor node metastasis $(113,136)$. In addition, H19 is considered as an important independent predictor for OS and DFS $(9,131)$, besides, $\mathrm{H} 19$ is the most significant lncRNA associated to CRC (130). Moreover, MALAT1 is one important negative prognostic marker in II/III CRC patients (145). Conversely, down regulation of Gas5 has been found in CRC and is associated with poor prognosis (100-104).

Interestingly, LncRNAs regulate multiples pathways in CRC as PI3K-AKT signaling pathway, that is regulated by GAS5, promoting apoptosis via GAS5/miR-182-5p/FOXO3a axis (101), as well as, PI3K/AKT/mTOR that is managed through HOTAIR/miR-326/FUT6 axis stimulating CRC (114). In addition, $\mathrm{H} 19$ regulates RAS-MAPK and $\mathrm{Wnt} / \beta$-catenin signaling pathways, activating invasion, metastasis, and chemoresistance mechanism $(133,134)$. Another important axis is MALAT1/miR-145/SOX9 that mediates cell cycle and apoptosis (146).

\section{LNCRNA AS REGULATORS OF AUTOPHAGY IN CRC}

Autophagy is a basal physiological mechanism in normal cells that assure cellular homeostasis. Besides, autophagy is a very well-conserved catabolic process where the cell is self-digested through the removal of proteins or dysfunctional organelles (150). This process can also be, under specific circumstances (hypoxia, stress, and nutrient deprivation), a survival mechanism in which the cell recycles nutrients and energy (151).

There are three forms of autophagy based on its morphology, macroautophagy in which autophagosomes engulf cytoplasmic components and interact whit lysosomes for degradation, microautophagy in which there is a direct lysosomal membrane invagination to engulf damaged proteins, and chaperonemediated autophagy which involves the translocation of soluble cytosolic proteins by chaperone-dependent selection across the lysosomal membrane (152-154).

LncRNAs generally modulate autophagy by regulating the expression of ATG genes which are important effectors in autophagy process $(155,156)$. Frequently, LncRNAs behaves 
as competing endogenous RNAs (ceRNAs) for modulating autophagy-related microRNAs (miRNAs). LncRNAs have a very important implication in autophagy regulation (155). For instance, activation of autophagy can be given by NBR2 via AMPK activation (157) or by repression of PI3K/AKT/mTOR pathway leaded by Ad5-AlncRNA, and PTENP1, whereas MEG3 and H19 enhances the opposite effect. Another LncRNAs involved in activation of autophagy are HOTAIRM1, PTENP1, and MALAT1, which increase the expression of ULK (158-162). Conversely, RISA suppress autophagy initiation through ULK1 inhibition (163). Additionally, key genes in autophagy such as ATG and adaptor proteins involved in later steps of autophagy regulation are affected by H19, MEG3, AK156230, PTENP1, and MALAT1(141, 158, 161, 164, 165).

It is clear that LncRNAs are non-canonical regulators and participates in keeping homeostasis in a variety of pathophysiological processes, but also they can be illness effectors, since they can interact directly with DNA, RNA, and proteins. In this regard, it has been demonstrated that autophagiaparticipates in cancer progression and drug resistance mechanisms (166). Besides, autophagy may suppress tumors (167), but also, their induction promotes tumorigenesis since it provide survival capacity of tumor under adverse microenvironment $(168,169)$.

In CRC, little is known about lncRNAs involved in autophagy, for instance, POU3F3, a lincRNA, is overexpressed in CRC tissue samples and when is silenced, autophagy is enhanced, suggesting the involvement of autophagy in the induction of apoptosis (170). Another lncRNA highly expressed in CRC is HAGLROS, which is correlated with shorter survival time of CRC patients and its decreased expression can produce apoptosis and suppress autophagy in CRC HCT116 cells by regulation of miR-100/ATG5 axis and PI3K/AKT/mTOR pathway (171).

UCA1 is also abnormally overexpressed in SW620 and HT29 CRC cell lines when compared to CCD-18Co. There is evidence that UCA1 downregulation inhibits the growth, apoptosis, and autophagy of CRC cell lines in vitro. Besides, UCA1 directly interacts with miR-185-5p downregulates its expression. Additionally, UCA1 could reverse this effect of miR185-5p on the growth and autophagy, suggesting its involvement in the derepression of WISP2 expression and the stimulation of the WISP2/ $\beta$-catenin signaling pathway (172).

Another lncRNA involved in CRC is KCNQ1OT1 (173), which is also upregulated. It has been demonstrated that expression patterns of Atg4B, which cleavages LC3 (thus promotes the formation of autophagosome) (174) is downregulated in CRC HCT116 and SW480 cells in KCNQ1OT1 knockdown cells. Besides, these cells treated with oxaliplatin, decrease cell viability, meaning that KCNQ1OT1 induce protective autophagy and chemoresistance. Finally, overexpression of KCNQ1OT1 is correlated with poor OS of CRC patients, suggesting that higher levels in patients make them resistant to chemotherapy treatments (173).

H19 is another upregulated lncRNA in CRC samples and has been correlated with patient OS suggesting that can predicts 5FU chemoresistance. These findings reveal that SIRT1 (which is modulated by H19/miR-194-5p axis) dependent autophagy pathway can affect 5-FU resistance in CRC cells (9).

There is no doubt that LncRNAs are key molecules involved in regulation of autophagy in CRC. Nevertheless, more research in this field is needed to clarify interactions on regulation axis in order to understand complex processes in which autophagy is implicated, such as apoptosis and chemoresistance.

\section{LNCRNA AS REGULATOR OF DRUG RESISTANCE IN CRC}

Malignant CRC tumors develop pharmacological resistance, which is a complex phenomenon that triggers increase in DNA repair and loss of apoptosis induction, resulting from several factors that include individual variation in patients such as genetic and/or epigenetic differences within the tumors $(7,175$, 176). Drug resistance is influenced by abnormal expression or mutation on efflux proteins, which reduce uptakes of drugs (177).

Chemotherapy for CRC depends on the stage of cancer; however, other factors are important as well. For stage 0 to II, surgical treatment alone might be successful, nonetheless, for stage II some oncologists opt for including 5-FU and leucovorin, oxaliplatin, or capecitabine if chemotherapy is needed (178-180). Treatment for stages III and IV includes chemo and/or targeted drugs, commonly include CAPEOX (capecitabine plus oxaliplatin), FOLFOX (oxaliplatin, 5-FU, and leucovorin), 5FU and leucovorin, or capecitabine for stage III and FOLFIRI (leucovorin, 5-FU, and irinotecan), FOLFOXIRI (leucovorin, 5FU, oxaliplatin, and irinotecan) plus some target drugs such as bevacizumab, ramucirimab, cetuximab, or panitumumab added for stage IV (181-186).

Regulation of gene expression by different types of non-coding RNAs such as miRNAs and lncRNAs are involved in acquisition of drug resistance characteristics after treatment (187). Most important dysregulated lncRNAs are summarized in Table 3. For instance, the characteristic acquisition of 5-FU resistance in CRC has been related with a plethora of lncRNAs missexpression. In the case of UCA-1, it plays an important role in 5 -FU chemoresponse by exerting a sponge activity to miR-204$5 \mathrm{p}$, thus, indirectly increases CREB1 which have been related with poor OS (172). Another LncRNA implicated in the development of 5-FU resistance is GIHCG, since its overexpression is found in both CRC tissues and cell lines and is related to invasion, migration, and chemoresistant properties (188). There is also evidence that downregulation of PVT1, MALAT1, and PCAT1 sensitizes CRC cells to 5-FU treatment, inducing early and late apoptosis by regulation of MDR genes $(193,194,196)$. On the other hand, downregulation of snaR and SLC25A25-AS1 promotes chemoresistance in CRC $(198,199)$.

Certain aspects of chemoresistance have been related with lncRNAs regulated by miRNAs, for instance, ENST00000547547 promotes sensitivity to $5-\mathrm{FU}$ in CRC cells by competitive arresting miR-31/ABCB9 (200) and LINC00152/miR-139$5 \mathrm{p} / \mathrm{NOTCH} 1$ axis increases chemoresistance by suppressing apoptosis (191). 
TABLE 3 | Long non-coding RNAs and their physiological function in colorectal cancer drug resistance.

\begin{tabular}{|c|c|c|}
\hline LncRNA & Function & References \\
\hline GIHCG & Potential target in 5-FU and Oxaliplatin resistance mechanisms. & $(188)$ \\
\hline MIR100HG & $\begin{array}{l}\text { Coordinately MIR100HG, miR-100 and miR-125b overexpression drives Cetuximab resistance by targeting } \\
\text { five negative regulators of Wnt signaling which have a potential clinical relevant interaction with EGFR. }\end{array}$ & $(189)$ \\
\hline UCA1 & $\begin{array}{l}\text { UCA1 can decrease the sensitivity of CRC cells to 5-FU by sponging miR-204-5p resulting in attenuating } \\
\text { apoptosis. Moreover, UCA1 expression levels are increased in Cetuximab resistant cells and can be } \\
\text { transferred to sensitive cells through exosomes increasing resistant cells number. }\end{array}$ & $(172,190)$ \\
\hline LINC00152 & $\begin{array}{l}\text { LIN00152 confers Oxa and 5-FU chemoresistance by sponging miR-193a-3p by ERBB4 modulation and } \\
\text { then inducing the activation of AKT signaling pathway that mediates cell survival and chemoresistance. } \\
\text { miR-193a-3p also targets NOTCH1 regulating CRC growth, metastasis, stemness, and chemoresistance. }\end{array}$ & $(191,192)$ \\
\hline HOTAIR & $\begin{array}{l}\text { HOTAIR could regulate the progression and Cisplatin and Paclitaxel chemoresistance enhancements in CRC } \\
\text { by targeting miR-203a-3p and the activity of Wnt/ } \beta \text {-catenin signaling pathway. }\end{array}$ & $(116)$ \\
\hline PCAT-1 & $\begin{array}{l}\text { PCAT-1 regulates the invasiveness and 5-FU resistance in CRC cells and that PCAT-1 may promote CRC cell } \\
\text { invasion by modulating the expression of C-Myc. }\end{array}$ & $(193)$ \\
\hline PVT1 & $\begin{array}{l}\text { PVT1 is associated with 5-FU resistance in human CRC tissues and cells by inhibiting apoptosis and } \\
\text { upregulating the expression of MRP1, P-gp, mTOR, and Bcl-2 }\end{array}$ & $(194)$ \\
\hline XIST & $\begin{array}{l}\text { XIST promotes Doxorubicin resistance through sponging miR-124 which targets SGK1 increasing cell } \\
\text { survival, loss of control in cell cycle, inhibiting apoptosis, and increasing chemoresistance. }\end{array}$ & $(195)$ \\
\hline MALAT1 & $\begin{array}{l}\text { Overexpression of MALAT1 enhances chemoresistance in 5-FU resistant cells through potentiation of } \\
\text { multidrug resistant genes such as MDR1, MRP1, BCRP, and ABC. Moreover, modulates EZH2 pathway in } \\
\text { Oxa resistance }\end{array}$ & $(196,197)$ \\
\hline $\mathrm{H} 19$ & $\begin{array}{l}\text { H19 mediated Methotrexate resistance via activating Wnt/ } \beta \text {-catenin signaling, which help to develop H19 as } \\
\text { a promising therapeutic target for MTX resistant CRC. Besides, CAFs promote stemness and Oxa } \\
\text { chemoresistance in CRC by transferring exosomal H19 to CRC sensitive cells through sponging miR-141. }\end{array}$ & $(20,134)$ \\
\hline SLC25A25-AS1 & $\begin{array}{l}\text { SLC25A25-AS1 has a pivotal role in CRC cells promoting chemo sensitivity to 5-FU and DOX via Erk and p38 } \\
\text { pathway modulation. Hence, SLC25A25-AS1 was determined to play a tumor suppressive role in CRC. }\end{array}$ & $(198)$ \\
\hline snaR & $\begin{array}{l}\text { snaR has a negative regulator role in responsible of the development of } 5 \text {-FU resistance through cell growth } \\
\text { of } \mathrm{CRC} \text { cells. Nonetheless, snaR detailed roles have not yet been established. }\end{array}$ & $(199)$ \\
\hline ENST00000547547 & $\begin{array}{l}\text { ENST00000547547 reduced the chemoresistance of 5-FU via competitive sponging to miR-31 which targets } \\
\text { ABCB9 involved in chemotherapy induced apoptosis. This suggests that IncRNA ENST00000547547 may } \\
\text { be a positive prognostic factor for 5-FU-based chemotherapy. }\end{array}$ & $(200)$ \\
\hline TUG1 & $\begin{array}{l}\text { TUG1 mediates MTX resistance in colorectal cancer via sponging miR-186 that targets CPEB2 increasing its } \\
\text { protein levels that play an important role in tumorigenesis and chemoresistance. }\end{array}$ & (201) \\
\hline PVT1 & $\begin{array}{l}\text { PVT1 is a significant regulator in tumorigenesis and cisplatin resistance of CRC by inhibiting apoptotic } \\
\text { pathways in } \mathrm{CRC} \text { and may serve as a promising target for CRC therapy. }\end{array}$ & (202) \\
\hline MEG3 & $\begin{array}{l}\text { MEG3 promotes chemosensitivity to Oxa by inducing cytotoxicity in CRC cells promoting apoptosis. In } \\
\text { addition, MEG3 sponges miR-141 that targets PDCD4. }\end{array}$ & $(203,204)$ \\
\hline
\end{tabular}

5-FU, 5-fluorouracil, Oxa, oxaliplatin. CAFs, cancer associated fibroblasts, DOX, doxorubicin.

In the case of oxaliplatin CRC treatment, several lncRNAs such as GIHCG (172), LIN00152 (192), MALAT1 (197), H19 (20), and MEG3 $(203,204)$ promote apoptosis by inducing cytotoxicity by different mechanisms, mainly by axis with miRNAs targeting important genes in cell death behavior. Nevertheless, cisplatin CRC resistance is mainly mediated by HOTAIR and PVT1 through inhibition of apoptotic pathways, modulation of expression levels of miR-203a-3p and the activity of Wnt $/ \beta$-catenin signaling pathway, respectively $(116,202)$.

Interestingly, $\mathrm{H} 19$ also exert drug resistance modulation in Methotrexate treatment via $\mathrm{Wnt} / \beta$-catenin signaling pathway (134). Regarding to TUG1, the resistance is given by CPBE2 gene modulation after arresting of miR-186 (201). Finally, Doxorubicin resistance is manly influenced by the XIST/miR124/SGK1 axis which promotes chemoresistance in CRC cells (195).

Evaluating lncRNAs expression profiles is very important since it can be used to identify novel biomarkers for CRC resistance and use them as a therapeutically potential targets based on their biological behavior, improving in this way, the efficacy of chemotherapy in CRC patients.

\section{CLINICAL RELEVANCE ON LNCRNA IN AUTOPHAGY AND DRUG RESISTANCE IN COLORECTAL CANCER}

Clinical implications of lncRNAs in CRC are relevant as there is evidence of its participation and correlation with staging and survival. In this regard, GAS5 down-regulation is common in CRC tissues being associated with distant metastasis, tumor differentiation, tumor size and advanced TNM staging (100), low histological grade (102), later tumor-node-metastasis stage and less OS (103).

Clinical relevance of $\mathrm{H} 19$ has been related with poor recurrent free survival (RFS) (9) tumor differentiation and advanced 
TNM stage, and is an independent predictor for OS and DFS. Moreover, previous studies using HOTAIR have determined that its overexpression is related to lymph node and, tumor node metastasis, distant metastases, Duke's staging, histological types, degree of differentiation (113) and poor clinical prognosis (114). Some studies show that it is upregulated in right CRCs biopsies (117). In addition, high levels of HOTAIR in tumors and blood are associated with higher mortality of patients (118).

MALAT1, patients have shown worse prognosis in tumors that appearance overexpression of this IncRNA in human primary CRC (145). In addition, MALAT1 have being related with lymph node metastasis in CRC patients (136).

Regarding to autophagy and chemoresistance in CRC, HAGLROS, a lncRNA related to autophagy, is correlated with shorter survival time (153). KCNQ1OT1, has also prove that induce protective autophagy and chemoresistance and its high expression is associated with poor OS of colon cancer patients, suggesting that patients with overexpression of KCNQ1OT1 might be resistant to chemotherapy treatments (173). Finally, $\mathrm{H} 19$ has been correlated with patient OS suggesting being a potential biomarker for predicting 5 -FU resistance that could be modulated by H19/miR-194-5p axis (157).

\section{CONCLUDING REMARKS}

Recently lncRNAs analysis is important for cancer detection, progression, diagnosis, therapy response, and prognostic values. With increasing development of quantitative detection techniques, lncRNAs derived from patients' non-invasive samples (i.e., blood, stools, and urine) has become into a novel approach in precision oncology.

\section{REFERENCES}

1. WHO. Cancer Fact Sheet. (2018). Available online at: http://www.who.int/ mediacentre/factsheets/fs297/en/ (accessed August 15, 2019).

2. Mishra DK, Veena U, Kaliki S, Kethiri AR, Sangwan VS, Ali $\mathrm{MH}$, et al. Differential expression of stem cell markers in ocular surface squamous neoplasia. PLoS ONE. (2016) 11:e0161800. doi: 10.1371/journal.pone.0161800

3. Brenner H, Kloor M, Pox CP. Colorectal cancer. Lancet. (2014) 383:1490502. doi: 10.1016/S0140-6736(13)61649-9

4. Li W, Zhang G, Wang HL, Wang L. Analysis of expression of cyclin E, p27kip1 and Ki67 protein in colorectal cancer tissues and its value for diagnosis, treatment and prognosis of disease. Eur Rev Med Pharmacol Sci. (2016) 20:4874-9.

5. Kurkjian C, Kummar S. Advances in the treatment of metastatic colorectal cancer. Am J Ther. (2009) 16:412-20. doi: 10.1097/MJT.0b013e3181907ed9

6. Holubec L, Polivka J, Safanda M, Karas M, Liska V. The role of cetuximab in the induction of anticancer immune response in colorectal cancer treatment. Anticancer Res. (2016) 36:4421-6. doi: 10.21873/anticanres.10985

7. Kang H, Kim C, Lee H, Kim W, Lee EK. Post-transcriptional controls by ribonucleoprotein complexes in the acquisition of drug resistance. Int J Mol Sci. (2013) 14:17204-20. doi: 10.3390/ijms140817204

8. Alfarouk KO, Stock C-M, Taylor S, Walsh M, Muddathir AK, Verduzco D, et al. Resistance to cancer chemotherapy: failure in drug response from ADME to P-gp. Cancer Cell Int. (2015) 15:71. doi: 10.1186/s12935-015-0221-1
Tumorspecific GAS5, HOTAIR, H19, and MALAT are novels CRC related IncRNAs detected in patients. Nonetheless, the effect and mechanism of lncRNAs in cancer autophagy and chemoresistance have not been extensively characterized.

Chemoresistance and autophagy are top issues for cancer treatment and lncRNAs play a pivotal role in resistance acquisition for several drugs. LncRNAs such as HAGLROS, KCNQ1OT1, and H19 are examples of IncRNA related to chemoresistance leaded by autophagy. Nevertheless, identifying the network interactions of lncRNAs can provide an insight in their mechanisms of action, adding clinical significance and hence, improve detection, diagnosis, and treatment.

\section{AUTHOR CONTRIBUTIONS}

MB, MA-M, EL-V, MA-F, and RR-P conceived and designed the content of this review and wrote the paper. ES-B and CL-C contributed to the final version of the manuscript.

\section{FUNDING}

Consejo Nacional de Ciencia y Tecnología CONACyT, Mexico (Grant 290311).

\section{ACKNOWLEDGMENTS}

The authors acknowledge CONACyT for MA-F (575985) and EL-V (304939) fellowships.

9. Wang M, Han D, Yuan Z, Hu H, Zhao Z, Yang R, et al. Long non-coding RNA $\mathrm{H} 19$ confers 5 -Fu resistance in colorectal cancer by promoting SIRT1-mediated autophagy. Cell Death Dis. (2018) 9:1149. doi: 10.1038/s41419-018-1187-4

10. Mah LY, Ryan KM. Autophagy and cancer. Cold Spring Harb Perspect Biol. (2012) 4:a008821. doi: 10.1101/cshperspect.a008821

11. Galluzzi L, Bravo-San Pedro JM, Levine B, Green DR, Kroemer G. Pharmacological modulation of autophagy: therapeutic potential and persisting obstacles. Nat Rev Drug Discov. (2017) 16:487-511. doi: 10.1038/nrd.2017.22

12. Mokarram P, Albokashy M, Zarghooni M, Moosavi MA, Sepehri Z, Chen QM, et al. New frontiers in the treatment of colorectal cancer: autophagy and the unfolded protein response as promising targets. Autophagy. (2017) 13:781-819. doi: 10.1080/15548627.2017.1290751

13. Patrushev LI, Kovalenko TF. Functions of noncoding sequences in mammalian genomes. Biochemistry. (2014) 79:1442-69. doi: 10.1134/S0006297914130021

14. Lanzafame M, Bianco G, Terracciano LM, Ng CKY. The role of long non-coding RNAs in hepatocarcinogenesis. Int J Mol Sci. (2018) 19:E682. doi: 10.3390/ijms19030682

15. Klinge CM. Non-coding RNAs: long non-coding RNAs and microRNAs in endocrine-related cancers. Endocr Relat Cancer. (2018) 25:R259-r82. doi: 10.1530/ERC-17-0548

16. Clark MB, Mattick JS. Long noncoding RNAs in cell biology. Semin Cell Dev Biol. (2011) 22:366-76. doi: 10.1016/j.semcdb.201 1.01 .001 
17. Guarino $\mathrm{M}$, rubino $\mathrm{B}$, ballabio g. The role of epithelial-mesenchymal transition in cancer pathology. Pathology. (2007) 39:305-18. doi: 10.1080/00313020701329914

18. Fang J, Sun C-C, Gong C. Long noncoding RNA XIST acts as an oncogene in non-small cell lung cancer by epigenetically repressing KLF2 expression. Biochem Biophys Res Commun. (2016) 478:811-7. doi: 10.1016/j.bbrc.2016.08.030

19. Zinovieva OL, Grineva EN, Prokofjeva MM, Karpov DS, Zheltukhin AO, Krasnov GS, et al. Expression of long non-coding RNA LINC00973 is consistently increased upon treatment of colon cancer cells with different chemotherapeutic drugs. Biochimie. (2018) 151:67-72. doi: 10.1016/j.biochi.2018.05.021

20. Ren J, Ding L, Zhang D, Shi G, Xu Q, Shen S, et al. Carcinoma-associated fibroblasts promote the stemness and chemoresistance of colorectal cancer by transferring exosomal lncRNA H19. Theranostics. (2018) 8:3932-48. doi: $10.7150 /$ thno. 25541

21. Yu ZY, Wang Z, Lee KY, Yuan P, Ding J. Effect of silencing colon cancer-associated transcript 2 on the proliferation, apoptosis and autophagy of gastric cancer BGC-823 cells. Oncol Lett. (2018) 15:3127-32. doi: 10.3892/ol.2017.7677

22. Kim ED, Sung S. Long noncoding RNA: unveiling hidden layer of gene regulatory networks. Trends Plant Sci. (2012) 17:16-21. doi: 10.1016/j.tplants.2011.10.008

23. Jia H, Osak M, Bogu GK, Stanton LW, Johnson R, Lipovich L. Genomewide computational identification and manual annotation of human long noncoding RNA genes. RNA. (2010) 16:1478-87. doi: 10.1261/rna.1951310

24. Cabili MN, Trapnell C, Goff L, Koziol M, Tazon-Vega B, Regev A, et al. Integrative annotation of human large intergenic noncoding RNAs reveals global properties and specific subclasses. Genes Dev. (2011) 25:1915-27. doi: $10.1101 / \mathrm{gad} .17446611$

25. Hombach S, Kretz M. Non-coding RNAs: classification, biology and functioning. Adv Exp Med Biol. (2016) 937:3-17. doi: 10.1007/978-3-319-42059-2_1

26. Chen LL. Linking long noncoding RNA localization and function. Trends Biochem Sci. (2016) 41:761-72. doi: 10.1016/j.tibs.2016.07.003

27. Jarroux J, Morillon A, Pinskaya M. History, discovery, and classification of IncRNAs. Adv Exp Med Biol. (2017) 1008:1-46. doi: 10.1007/978-981-10-5203-3_1

28. Kashi K, Henderson L, Bonetti A, Carninci P. Discovery and functional analysis of lncRNAs: methodologies to investigate an uncharacterized transcriptome. Biochim Biophys Acta. (2016) 1859:3-15. doi: 10.1016/j.bbagrm.2015.10.010

29. Spurlock CF III, Crooke PS III, Aune TM. Biogenesis and transcriptional regulation of long noncoding RNAs in the human immune system. $J$ Immunol. (2016) 197:4509-17. doi: 10.4049/jimmunol.1600970

30. Clark MB, Amaral PP, Schlesinger FJ, Dinger ME, Taft RJ, Rinn JL, et al. The reality of pervasive transcription. PLoS Biol. (2011) 9:e1000625-e1102. doi: 10.1371/journal.pbio.1000625

31. Hangauer MJ, Vaughn IW, McManus MT. Pervasive transcription of the human genome produces thousands of previously unidentified long intergenic noncoding RNAs. PLoS Genet. (2013) 9:e1003569. doi: 10.1371/journal.pgen.1003569

32. $\mathrm{Yu} \mathrm{AD}$, Wang $\mathrm{Z}$, Morris KV. Long noncoding RNAs: a potent source of regulation in immunity and disease. Immunol Cell Biol. (2015) 93:277-83. doi: $10.1038 /$ icb. 2015.2

33. Khachane AN, Harrison PM. Mining mammalian transcript data for functional long non-coding RNAs. PLoS ONE. (2010) 5:e10316. doi: 10.1371/journal.pone.0010316

34. Moran VA, Perera RJ, Khalil AM. Emerging functional and mechanistic paradigms of mammalian long non-coding RNAs. Nucleic Acids Res. (2012) 40:6391-400. doi: 10.1093/nar/gks296

35. Aune TM, Crooke PS, Spurlock CF. Long noncoding RNAs in $T$ lymphocytes. J Leukoc Biol. (2016) 99:31-44. doi: 10.1189/jlb.1RI0815-389R

36. Mattick JS, Rinn JL. Discovery and annotation of long noncoding RNAs. Nat Struct Mol Biol. (2015) 22:5-7. doi: 10.1038/nsmb.2942

37. Guttman M, Rinn JL. Modular regulatory principles of large non-coding RNAs. Nature. (2012) 482:339-46. doi: 10.1038/nature10887
38. Rinn JL, Chang HY. Genome regulation by long noncoding RNAs. Annu Rev Biochem. (2012) 81:145-66. doi: 10.1146/annurev-biochem-051410-092902

39. Lam MT, Li W, Rosenfeld MG, Glass CK. Enhancer RNAs and regulated transcriptional programs. Trends Biochem Sci. (2014) 39:170-82. doi: 10.1016/j.tibs.2014.02.007

40. Cabili MN, Dunagin MC, McClanahan PD, Biaesch A, Padovan-Merhar O, Regev A, et al. Localization and abundance analysis of human lncRNAs at single-cell and single-molecule resolution. Genome Biol. (2015) 16:20. doi: 10.1186/s13059-015-0586-4

41. Naganuma T, Hirose T. Paraspeckle formation during the biogenesis of long non-coding RNAs. RNA Biol. (2013) 10:456-61. doi: 10.4161/rna.23547

42. Quinodoz S, Guttman M. Long noncoding RNAs: an emerging link between gene regulation and nuclear organization. Trends Cell Biol. (2014) 24:651-63. doi: 10.1016/j.tcb.2014.08.009

43. Tay Y, Rinn J, Pandolfi PP. The multilayered complexity of ceRNA crosstalk and competition. Nature. (2014) 505:344-52. doi: 10.1038/nature12986

44. Bonasio R, Shiekhattar R. Regulation of transcription by long noncoding RNAs. Annu Rev Genet. (2014) 48:433-55. doi: 10.1146/annurev-genet-120213-092323

45. Ferre F, Colantoni A, Helmer-Citterich M. Revealing protein-lncRNA interaction. Brief Bioinform. (2016) 17:106-16. doi: 10.1093/bib/bbv031

46. Xu Y, Wu W, Han Q, Wang Y, Li C, Zhang P, et al. New insights into the interplay between non-coding RNAs and RNA-binding protein HnRNPK in regulating cellular functions. Cells. (2019) 8:62. doi: 10.3390/cells8010062

47. Yoon J-H, Abdelmohsen K, Kim J, Yang X, Martindale JL, TominagaYamanaka K, et al. Scaffold function of long non-coding RNA HOTAIR in protein ubiquitination. Nat Commun. (2013) 4:2939. doi: $10.1038 /$ ncomms 3939

48. Uchida S. High-throughput methods to detect long non-coding RNAs. High Throughput. (2017) 6:12. doi: 10.3390/6030012

49. Lodish HF. Molecular Cell Biology. 6th ed. Basingstoke: W.H. Freeman (2008).

50. Shi Y, Shang J. Long noncoding RNA expression profiling using arraystar LncRNA microarrays. Methods Mol Biol. (2016) 1402:43-61. doi: 10.1007/978-1-4939-3378-5_6

51. Iempridee T, Wiwithaphon S, Piboonprai K, Pratedrat P, Khumkhrong $\mathrm{P}$, Japrung $\mathrm{D}$, et al. Identification of reference genes for circulating long noncoding RNA analysis in serum of cervical cancer patients. FEBS Open Bio. (2018) 8:1844-54. doi: 10.1002/2211-5463.12523

52. Yang JP, Yang XJ, Xiao L, Wang Y. Long noncoding RNA PVT1 as a novel serum biomarker for detection of cervical cancer. Eur Rev Med Pharmacol Sci. (2016) 20:3980-6.

53. Lin $\mathrm{Y}$, Leng Q, Zhan M, Jiang F. A plasma long noncoding RNA signature for early detection of lung cancer. Transl Oncol. (2018) 11:1225-31. doi: 10.1016/j.tranon.2018.07.016

54. Pan Y, Chen H, Shen X, Wang X, Ju S, Lu M, et al. Serum level of long noncoding RNA H19 as a diagnostic biomarker of multiple myeloma. Clin Chim Acta. (2018) 480:199-205. doi: 10.1016/j.cca.2018.02.019

55. Liu $\mathrm{T}$, Zhang $\mathrm{X}$, Gao S, Jing $\mathrm{F}$, Yang $\mathrm{Y}$, Du L, et al. Exosomal long noncoding RNA CRNDE-h as a novel serum-based biomarker for diagnosis and prognosis of colorectal cancer. Oncotarget. (2016) 7:85551-63. doi: 10.18632/oncotarget.13465

56. Qi P, Dong L, Lin W, Zhou X, Du X. Abstract B42: a two-lncRNA signature in serous exosomes serves as a new biomarker for colorectal cancer diagnosis. Cancer Res. (2016) 76 (Suppl. 6):B42.

57. Hu D, Zhan Y, Zhu K, Bai M, Han J, Si Y, et al. Plasma exosomal long noncoding RNAs serve as biomarkers for early detection of colorectal cancer. Cell Physiol Biochem. (2018) 51:2704-15. doi: 10.1159/000495961

58. Yu X, Yuan Z, Yang Z, Chen D, Kim T, Cui Y, et al. The novel long noncoding RNA u50535 promotes colorectal cancer growth and metastasis by regulating CCL20. Cell Death Dis. (2018) 9:751. doi: 10.1038/s41419-018-0771-y

59. Lin LY, Yang L, Zeng Q, Wang L, Chen ML, Zhao ZH, et al. Tumor-originated exosomal lncUEGC1 as a circulating biomarker for early-stage gastric cancer. Mol Cancer. (2018) 17:1-6. doi: 10.1186/s12943-018-0834-9

60. Arita T, Ichikawa D, Konishi H, Komatsu S, Shiozaki A, Shoda K, et al. Circulating long non-coding RNAs in plasma of patients with gastric cancer. Anticancer Res. (2013) 33:3185-94. 
61. Sun L, Su Y, Liu X, Xu M, Chen X, Zhu Y, et al. Serum and exosome long non coding RNAs as potential biomarkers for hepatocellular carcinoma. J Cancer. (2018) 9:2631-9. doi: 10.7150/jca.24978

62. Bolha L, Ravnik-Glavač M, Glavač D. Long noncoding RNAs as biomarkers in cancer. Disease Markers. (2017) 2017:1-14. doi: 10.1155/2017/7243968

63. Qi P, Zhou Xy, Du X. Circulating long non-coding RNAs in cancer: current status and future perspectives. Mol Cancer. (2016) 15:1-11. doi: 10.1186/s12943-016-0524-4

64. Du L, Duan W, Jiang X, Zhao L, Li J, Wang R, et al. Cell-free lncRNA expression signatures in urine serve as novel non-invasive biomarkers for diagnosis and recurrence prediction of bladder cancer. J Cell Mol Med. (2018) 22:2838-45. doi: $10.1111 /$ jcmm.13578

65. Lorenzen JM, Schauerte C, Kölling M, Hu A, Knapp M. Long noncoding RNAs in urine are detectable and may enable early detection of acute T cell-mediated rejection of renal allografts. Clin Chem. (2015) 61:1505-14. doi: 10.1373/clinchem.2015.243600

66. Hu B, Yang H, Yang H. Diagnostic value of urine prostate cancer antigen 3 test using a cutoff value of $35 \mathrm{mug} / \mathrm{L}$ in patients with prostate cancer. Tumour Biol. (2014) 35:8573-80. doi: 10.1007/s13277-014-2109-4

67. Xue W-J, Ying X-L, Jiang J-H, Xu Y-H. Prostate cancer antigen 3 as a biomarker in the urine for prostate cancer diagnosis: a meta-analysis. J Cancer Res Ther. (2014) 10 (Suppl. 1):C218-21. doi: 10.4103/0973-1482.145881

68. Sartori DA, Chan DW. Biomarkers in prostate cancer: what's new? Curr Opin Oncol. (2014) 26:259-64. doi: 10.1097/CCO.0000000000000065

69. Tang H, Wu Z, Zhang J, Su B. Salivary lncRNA as a potential marker for oral squamous cell carcinoma diagnosis. Mol Med Rep. (2013) 7:761-6. doi: $10.3892 / \mathrm{mmr} .2012 .1254$

70. Huarte M, Rinn JL. Large non-coding RNAs: missing links in cancer? Human Mol Genet. (2010) 19:R152-61. doi: 10.1093/hmg/ddq353

71. Taft RJ, Pang KC, Mercer TR, Dinger M, Mattick JS. Non-coding RNAs: regulators of disease. J Pathol. (2010) 220:126-39. doi: 10.1002/pat h.2638

72. Parasramka MA, Maji S, Matsuda A, Yan IK, Patel T. Long non-coding RNAs as novel targets for therapy in hepatocellular carcinoma. Pharmacol Ther. (2016) 161:67-78. doi: 10.1016/j.pharmthera.2016.03.004

73. Zeng S, Xiao YF, Tang B, Hu CJ, Xie R, Yang SM, et al. Long noncoding RNA in digestive tract cancers: function, mechanism, and potential biomarker. Oncologist. (2015) 20:898-906. doi: 10.1634/theoncologist.2014-0475

74. Sun J, Li W, Sun Y, Yu D, Wen X, Wang H, et al. A novel antisense long noncoding RNA within the IGF1R gene locus is imprinted in hematopoietic malignancies. Nucleic Acids Res. (2014) 42:9588-601. doi: 10.1093/nar/gku549

75. Martens-Uzunova ES, Bottcher R, Croce CM, Jenster G, Visakorpi T, Calin GA. Long noncoding RNA in prostate, bladder, and kidney cancer. Eur Urol. (2014) 65:1140-51. doi: 10.1016/j.eururo.2013.12.003

76. Ricciuti B, Mencaroni C, Paglialunga L, Paciullo F, Crino L, Chiari $\mathrm{R}$, et al. Long noncoding RNAs: new insights into non-small cell lung cancer biology, diagnosis and therapy. Med Oncol. (2016) 33:18. doi: $10.1007 /$ s12032-016-0731-2

77. Shi Y, Li J, Liu Y, Ding J, Fan Y, Tian Y, et al. The long noncoding RNA SPRY4-IT1 increases the proliferation of human breast cancer cells by upregulating ZNF703 expression. Mol Cancer. (2015) 14:51. doi: 10.1186/s12943-015-0318-0

78. Shi Y, Liu Y, Wang J, Jie D, Yun T, Li W, et al. Downregulated long noncoding RNA BANCR promotes the proliferation of colorectal cancer cells via downregualtion of p21 expression. PLoS ONE. (2015) 10:e0122679. doi: 10.1371/journal.pone.0122679

79. Jin Y, Feng SJ, Qiu S, Shao N, Zheng JH. LncRNA MALAT1 promotes proliferation and metastasis in epithelial ovarian cancer via the PI3K-AKT pathway. Eur Rev Med Pharmacol Sci. (2017) 21:3176-84.

80. Ge X, Chen Y, Liao X, Liu D, Li F, Ruan H, et al. Overexpression of long noncoding RNA PCAT-1 is a novel biomarker of poor prognosis in patients with colorectal cancer. Med Oncol. (2013) 30:588. doi: 10.1007/s12032-013-0588-6

81. Fu J, Cui Y. Long noncoding RNA ZEB1-AS1 expression predicts progression and poor prognosis of colorectal cancer. Int J Biol Markers. (2017) 32:e428e33. doi: 10.5301/ijbm. 5000303
82. Li Y, Zhao L, Zhang Y, Guan L, Zhang H, Zhou H, et al. Downregulation of the long non-coding RNA XLOC_010588 inhibits the invasion and migration of colorectal cancer. Oncol Rep. (2018) 39:1619-30. doi: 10.3892/or.2018.6260

83. Yang $\mathrm{Y}$, Zhang J, Chen $\mathrm{X}, \mathrm{Xu} \mathrm{X}, \mathrm{Cao} \mathrm{G}, \mathrm{Li} \mathrm{H}$, et al. LncRNA FTX sponges miR-215 and inhibits phosphorylation of vimentin for promoting colorectal cancer progression. Gene Ther. (2018) 25:321-30. doi: 10.1038/s41434-018-0026-7

84. Su J, Zhang E, Han L, Yin D, Liu Z, He X, et al. Long noncoding RNA BLACAT1 indicates a poor prognosis of colorectal cancer and affects cell proliferation by epigenetically silencing of p15. Cell Death Dis. (2017) 8:e2665. doi: 10.1038/cddis.2017.83

85. Han Q, Xu L, Lin W, Yao X, Jiang M, Zhou R, et al. Long noncoding RNA CRCMSL suppresses tumor invasive and metastasis in colorectal carcinoma through nucleocytoplasmic shuttling of HMGB2. Oncogene. (2019) 38:301932. doi: 10.1038/s41388-018-0614-4

86. Wang Y, Lu Z, Wang N, Feng J, Zhang J, Luan L, et al. Long noncoding RNA DANCR promotes colorectal cancer proliferation and metastasis via miR577 sponging. Exp Mol Med. (2018) 50:57. doi: 10.1038/s12276-018-0082-5

87. Gu LQ, Xing XL, Cai H, Si AF, Hu XR, Ma QY, et al. Long non-coding RNA DILC suppresses cell proliferation and metastasis in colorectal cancer. Gene. (2018) 666:18-26. doi: 10.1016/j.gene.2018.03.100

88. Zhong $\mathrm{X}, \mathrm{Lu} \mathrm{M}$, Wan J, Zhou T, Qin B. Long noncoding RNA kcna3 inhibits the progression of colorectal carcinoma through downregulating YAP1 expression. Biomed Pharmacother. (2018) 107:382-9. doi: 10.1016/j.biopha.2018.07.118

89. Ding J, Lu B, Wang J, Wang J, Shi Y, Lian Y, et al. Long noncoding RNA Loc554202 induces apoptosis in colorectal cancer cells via the caspase cleavage cascades. J Exp Clin Cancer Res. (2015) 34:100. doi: 10.1186/s13046-015-0217-7

90. Ji H, Hui B, Wang J, Zhu Y, Tang L, Peng P, et al. Long noncoding RNA MAPKAPK5-AS1 promotes colorectal cancer proliferation by partly silencing p21 expression. Cancer Sci. (2019) 110:72-85. doi: $10.1111 /$ cas. 13838

91. Shi L, Hong X, Ba L, He X, Xiong Y, Ding Q, et al. Long noncoding RNA ZNFX1-AS1 promotes the tumor progression and metastasis of colorectal cancer by acting as a competing endogenous RNA of miR-144 to regulate EZH2 expression. Cell Death Dis. (2019) 10:150. doi: 10.1038/s41419-019-1332-8

92. Lian $\mathrm{Y}, \mathrm{Xu} \mathrm{Y}, \mathrm{Xiao} \mathrm{C}$, Xia R, Gong H, Yang $\mathrm{P}$, et al. The pseudogene derived from long non-coding RNA DUXAP10 promotes colorectal cancer cell growth through epigenetically silencing of p21 and PTEN. Sci Rep. (2017) 7:7312. doi: 10.1038/s41598-017-07954-7

93. Wang Q, Yang L, Hu X, Jiang Y, Hu Y, Liu Z, et al. Upregulated NNTAS1, a long noncoding RNA, contributes to proliferation and migration of colorectal cancer cells in vitro and in vivo. Oncotarget. (2017) 8:3441-53. doi: 10.18632/oncotarget.13840

94. Deng Q, He B, Gao T, Pan Y, Sun H, Xu Y, et al. Up-regulation of $91 \mathrm{H}$ promotes tumor metastasis and predicts poor prognosis for patients with colorectal cancer. PLoS ONE. (2014) 9:e103022. doi: 10.1371/journal.pone.0103022

95. Kino T, Hurt DE, Ichijo T, Nader N, Chrousos GP. Noncoding RNA gas5 is a growth arrest- and starvation-associated repressor of the glucocorticoid receptor. Sci Signal. (2010) 3:ra8-ra. doi: 10.1126/scisignal.2000568

96. Pickard MR, Williams GT. Molecular and cellular mechanisms of action of tumour suppressor GAS5 LncRNA. Genes. (2015) 6:484-99. doi: $10.3390 /$ genes6030484

97. Pickard MR, Mourtada-Maarabouni M, Williams GT. Long non-coding RNA GAS5 regulates apoptosis in prostate cancer cell lines. Biochim Biophys Acta. (2013) 1832:1613-23. doi: 10.1016/j.bbadis.2013.05.005

98. Qiao HP, Gao WS, Huo JX, Yang ZS. Long non-coding RNA GAS5 functions as a tumor suppressor in renal cell carcinoma. Asian Pacific J Cancer Prevent. (2013) 14:1077-82. doi: 10.7314/APJCP.2013.14.2.1077

99. Mourtada-Maarabouni M, Pickard MR, Hedge VL, Farzaneh F, Williams GT. GAS5, a non-protein-coding RNA, controls apoptosis and is downregulated in breast cancer. Oncogene. (2009) 28:195-208. doi: 10.1038/onc.2008.373

100. Li J, Wang Y, Zhang C-G, Xiao H-J, Hou J-M, He J-D. Effect of long non-coding RNA Gas5 on proliferation, migration, invasion and 
apoptosis of colorectal cancer HT-29 cell line. Cancer Cell Int. (2018) 18:4. doi: 10.1186/s12935-017-0478-7

101. Cheng K, Zhao Z, Wang G, Wang J, Zhu W. IncRNA GAS5 inhibits colorectal cancer cell proliferation via the miR1825p/FOXO3a axis. Oncol Rep. (2018) 40:2371-80. doi: 10.3892/or.2018.6584

102. Yin D, He X, Zhang E, Kong R, De W, Zhang Z. Long noncoding RNA GAS5 affects cell proliferation and predicts a poor prognosis in patients with colorectal cancer. Med Oncol. (2014) 31:253. doi: 10.1007/s12032-014-0253-8

103. Yang Y, Shen Z, Yan Y, Wang B, Zhang J, Shen C, et al. Long non-coding RNA GAS5 inhibits cell proliferation, induces G0/G1 arrest and apoptosis, and functions as a prognostic marker in colorectal cancer. Oncol Lett. (2017) 13:3151-8. doi: 10.3892/ol.2017.5841

104. Liu L, Meng T, Yang XH, Sayim P, Lei C, Jin B, et al. Prognostic and predictive value of long non-coding RNA GAS5 and mircoRNA-221 in colorectal cancer and their effects on colorectal cancer cell proliferation, migration and invasion. Cancer Biomarkers. (2018) 22:283-99. doi: 10.3233/CBM-171011

105. Song J, Shu H, Zhang L, Xiong J. Long noncoding RNA GAS5 inhibits angiogenesis and metastasis of colorectal cancer through the Wnt/beta-catenin signaling pathway. J Cell Biochem. (2019) 2019:27743. doi: $10.1002 / j c b .27743$

106. Rinn JL, Kertesz M, Wang JK, Squazzo SL, Xu X, Brugmann SA, et al. Functional demarcation of active and silent chromatin domains in human HOX loci by noncoding RNAs. Cell. (2007) 129:1311-23. doi: 10.1016/j.cell.2007.05.022

107. Zeng X, Chen S, Huang H. Phosphorylation of EZH2 by CDK1 and CDK2: a possible regulatory mechanism of transmission of the H3K27me3 epigenetic mark through cell divisions. Cell Cycle. (2011) 10:579-83. doi: $10.4161 /$ cc.10.4.14722

108. Ding J, Yeh C-R, Sun Y, Lin C, Chou J, Ou Z, et al. Estrogen receptor $\beta$ promotes renal cell carcinoma progression via regulating LncRNA HOTAIR-miR-138/200c/204/217 associated CeRNA network. Oncogene. (2018) 37:5037-53. doi: 10.1038/s41388-018-0175-6

109. Gupta RA, Shah N, Wang KC, Kim J, Horlings HM, Wong DJ, et al. Long non-coding RNA HOTAIR reprograms chromatin state to promote cancer metastasis. Nature. (2010) 464:1071-6. doi: 10.1038/nature08975

110. Liu XH, Sun $M$, Nie FQ, Ge YB, Zhang EB, Yin DD, et al. Lnc RNA HOTAIR functions as a competing endogenous RNA to regulate HER2 expression by sponging miR-331-3p in gastric cancer. Mol Cancer. (2014) 13:92. doi: 10.1186/1476-4598-13-92

111. Liu XH, Liu ZL, Sun M, Liu J, Wang ZX, De W. The long non-coding RNA HOTAIR indicates a poor prognosis and promotes metastasis in non-small cell lung cancer. BMC Cancer. (2013) 13:464. doi: 10.1186/1471-2407-13-464

112. Zhang Z, Cheng J, Wu Y, Qiu J, Sun Y, Tong X. LncRNA HOTAIR controls the expression of Rab22a by sponging miR-373 in ovarian cancer. Mol Med Rep. (2016) 14:2465-72. doi: 10.3892/mmr.2016.5572

113. Lin K, Jiang H, Zhang LL, Jiang Y, Yang YX, Qiu GD, et al. Downregulated LncRNA-HOTAIR suppressed colorectal cancer cell proliferation, invasion, and migration by mediating p21. Digest Dis Sci. (2018) 63:2320-31. doi: 10.1007/s10620-018-5127-z

114. Pan S, Liu Y, Liu Q, Xiao Y, Liu B, Ren X, et al. HOTAIR/miR-326/FUT6 axis facilitates colorectal cancer progression through regulating fucosylation of CD44 via PI3K/AKT/mTOR pathway. Biochim Biophys Acta Mol Cell Res. (2019) 1866:750-60. doi: 10.1016/j.bbamcr.2019.02.004

115. Yang XD, Xu HT, Xu XH, Ru G, Liu W, Zhu JJ, et al. Knockdown of long non-coding RNA HOTAIR inhibits proliferation and invasiveness and improves radiosensitivity in colorectal cancer. Oncol Rep. (2016) 35:479-87. doi: 10.3892/or.2015.4397

116. Xiao Z, Qu Z, Chen Z, Fang Z, Zhou K, Huang Z, et al. LncRNA HOTAIR is a prognostic biomarker for the proliferation and chemoresistance of colorectal cancer via MiR-203a-3p-mediated Wnt/ss-catenin signaling pathway. Cell Physiol Biochem. (2018) 46:1275-85. doi: 10.1159/0004 89110

117. Tatangelo F, Di Mauro A, Scognamiglio G, Aquino G, Lettiero A, Delrio $\mathrm{P}$, et al. Posterior HOX genes and HOTAIR expression in the proximal and distal colon cancer pathogenesis. J Transl Med. (2018) 16:350. doi: 10.1186/s12967-018-1725-y

118. Svoboda M, Slyskova J, Schneiderova M, Makovicky P, Bielik L, Levy M, et al. HOTAIR long non-coding RNA is a negative prognostic factor not only in primary tumors, but also in the blood of colorectal cancer patients. Carcinogenesis. (2014) 35:1510-5. doi: 10.1093/carcin/bgu055

119. Gabory A, Ripoche MA, Yoshimizu T, Dandolo L. The H19 gene: regulation and function of a non-coding RNA. Cytogenet Genome Res. (2006) 113:18893. doi: $10.1159 / 000090831$

120. Gabory A, Jammes H, Dandolo L. The H19 locus: role of an imprinted non-coding RNA in growth and development. Bioessays. (2010) 32:473-80. doi: 10.1002/bies.200900170

121. Brannan CI, Dees EC, Ingram RS, Tilghman SM. The product of the H19 gene may function as an RNA. Mol Cell Biol. (1990) 10:28-36. doi: 10.1128/MCB.10.1.28

122. Lustig O, Ariel I, Ilan J, Lev-Lehman E, De-Groot N, Hochberg A. Expression of the imprinted gene H19 in the human fetus. Mol Reprod Dev. (1994) 38:239-46. doi: $10.1002 / \mathrm{mrd} .1080380302$

123. Ariel I, Miao HQ, Ji XR, Schneider T, Roll D, de Groot N, et al. Imprinted H19 oncofetal RNA is a candidate tumour marker for hepatocellular carcinoma. Mol Pathol. (1998) 51:21-5. doi: 10.1136/mp.51.1.21

124. Hibi K, Nakamura H, Hirai A, Fujikake Y, Kasai Y, Akiyama S, et al. Loss of H19 imprinting in esophageal cancer. Cancer Res. (1996) 56:480-2.

125. Tanos V, Prus D, Ayesh S, Weinstein D, Tykocinski ML, De-Groot $\mathrm{N}$, et al. Expression of the imprinted H19 oncofetal RNA in epithelial ovarian cancer. Eur J Obstetr Gynecol Reprod Biol. (1999) 85:7-11. doi: 10.1016/S0301-2115(98)00275-9

126. Berteaux N, Lottin S, Monte D, Pinte S, Quatannens B, Coll J, et al. H19 mRNA-like noncoding RNA promotes breast cancer cell proliferation through positive control by E2F1. J Biol Chem. (2005) 280:29625-36. doi: 10.1074/jbc.M504033200

127. Byun HM, Wong HL, Birnstein EA, Wolff EM, Liang G, Yang AS. Examination of IGF2 and H19 loss of imprinting in bladder cancer. Cancer Res. (2007) 67:10753-8. doi: 10.1158/0008-5472.CAN-07-0329

128. Yang W, Ning N. The lncRNA H19 promotes cell proliferation by competitively binding to miR-200a and derepressing beta-catenin expression in colorectal cancer. Biomed Res Int. (2017) 2017:2767484. doi: 10.1155/2017/2767484

129. Tsang WP, Ng EK, Ng SS, Jin H, Yu J, Sung JJ, et al. Oncofetal H19derived miR-675 regulates tumor suppressor RB in human colorectal cancer. Carcinogenesis. (2010) 31:350-8. doi: 10.1093/carcin/bgp181

130. Ohtsuka M, Ling H, Ivan C, Pichler M, Matsushita D, Goblirsch M, et al. H19 noncoding RNA, an independent prognostic factor, regulates essential RbE2F and CDK8-beta-catenin signaling in colorectal cancer. EBio Med. (2016) 13:113-24. doi: 10.1016/j.ebiom.2016.10.026

131. Han D, Gao X, Wang M, Qiao Y, Xu Y, Yang J, et al. Long noncoding RNA H19 indicates a poor prognosis of colorectal cancer and promotes tumor growth by recruiting and binding to eIF4A3. Oncotarget. (2016) 7:22159-73. doi: 10.18632/oncotarget.8063

132. Ding D, Li C, Zhao T, Li D, Yang L, Zhang B. LncRNA H19/miR-29b3p/PGRN axis promoted epithelial-mesenchymal transition of colorectal cancer cells by acting on Wnt signaling. Mol Cells. (2018) 41:423-35. doi: 10.14348/molcells.2018.2258

133. Yang W, Redpath RE, Zhang C, Ning N. Long non-coding RNA H19 promotes the migration and invasion of colon cancer cells via MAPK signaling pathway. Oncol Lett. (2018) 16:3365-72. doi: 10.3892/ol.2018.9052

134. Wu KF, Liang WC, Feng L, Pang JX, Waye MM, Zhang JF, et al. H19 mediates methotrexate resistance in colorectal cancer through activating Wnt/beta-catenin pathway. Exp Cell Res. (2017) 350:312-7. doi: 10.1016/j.yexcr.2016.12.003

135. Liang WC, Fu WM, Wong CW, Wang Y, Wang WM, Hu GX, et al. The IncRNA H19 promotes epithelial to mesenchymal transition by functioning as miRNA sponges in colorectal cancer. Oncotarget. (2015) 6:22513-25. doi: 10.18632/oncotarget.4154

136. Yang MH, Hu ZY, Xu C, Xie LY, Wang XY, Chen SY, et al. MALAT1 promotes colorectal cancer cell proliferation/migration/invasion via PRKA kinase anchor protein 9. Biochim Biophys Acta. (2015) 1852:166-74. doi: 10.1016/j.bbadis.2014.11.013

137. Ji P, Diederichs S, Wang W, Boing S, Metzger R, Schneider PM, et al. MALAT-1, a novel noncoding RNA, and thymosin beta4 predict metastasis and survival in early-stage non-small cell lung cancer. Oncogene. (2003) 22:8031-41. doi: 10.1038/sj.onc.1206928 
138. Tseng JJ, Hsieh YT, Hsu SL, Chou MM. Metastasis associated lung adenocarcinoma transcript 1 is up-regulated in placenta previa increta/percreta and strongly associated with trophoblast-like cell invasion in vitro. Mol Hum Reprod. (2009) 15:725-31. doi: 10.1093/molehr/gap071

139. Lin R, Maeda S, Liu C, Karin M, Edgington TS. A large noncoding RNA is a marker for murine hepatocellular carcinomas and a spectrum of human carcinomas. Oncogene. (2007) 26:851-8. doi: 10.1038/sj.onc.1209846

140. Guo F, Li Y, Liu Y, Wang J, Li Y, Li G. Inhibition of metastasis-associated lung adenocarcinoma transcript 1 in CaSki human cervical cancer cells suppresses cell proliferation and invasion. Acta Biochim Biophys Sin. (2010) 42:224-9. doi: 10.1093/abbs/gmq008

141. Schmidt LH, Spieker T, Koschmieder S, Schaffers S, Humberg J, Jungen D, et al. The long noncoding MALAT-1 RNA indicates a poor prognosis in nonsmall cell lung cancer and induces migration and tumor growth. $J$ Thoracic Oncol. (2011) 6:1984-92. doi: 10.1097/JTO.0b013e3182307eac

142. Ying L, Chen Q, Wang Y, Zhou Z, Huang Y, Qiu F. Upregulated MALAT-1 contributes to bladder cancer cell migration by inducing epithelial-to-mesenchymal transition. Mol Biosystems. (2012) 8:2289-94. doi: $10.1039 / \mathrm{c} 2 \mathrm{mb} 25070 \mathrm{e}$

143. Gutschner T, Hammerle M, Eissmann M, Hsu J, Kim Y, Hung G, et al. The noncoding RNA MALAT1 is a critical regulator of the metastasis phenotype of lung cancer cells. Cancer Res. (2013) 73:1180-9. doi: 10.1158/0008-5472.CAN-12-2850

144. Yamada K, Kano J, Tsunoda H, Yoshikawa H, Okubo C, Ishiyama T, et al. Phenotypic characterization of endometrial stromal sarcoma of the uterus. Cancer Sci. (2006) 97:106-12. doi: 10.1111/j.1349-7006.2006.00147.x

145. Zheng HT, Shi DB, Wang YW, Li XX, Xu Y, Tripathi P, et al. High expression of lncRNA MALAT1 suggests a biomarker of poor prognosis in colorectal cancer. Int J Clin Exp Pathol. (2014) 7:3174-81.

146. Xu Y, Zhang X, Hu X, Zhou W, Zhang $\mathrm{P}$, Zhang J, et al. The effects of lncRNA MALAT1 on proliferation, invasion and migration in colorectal cancer through regulating SOX9. Mol Med. (2018) 24:52. doi: 10.1186/s10020-018-0050-5

147. Ji Q, Zhang L, Liu X, Zhou L, Wang W, Han Z, et al. Long non-coding RNA MALAT1 promotes tumour growth and metastasis in colorectal cancer through binding to SFPQ and releasing oncogene PTBP2 from SFPQ/PTBP2 complex. Br J Cancer. (2014) 111:736-48. doi: 10.1038/bjc.2014.383

148. Sun Z, Ou C, Liu J, Chen C, Zhou Q, Yang S, et al. YAP1-induced MALAT1 promotes epithelial-mesenchymal transition and angiogenesis by sponging miR-126-5p in colorectal cancer. Oncogene. (2019) 38:2627-44. doi: 10.1038/s41388-018-0628-y

149. Tang D, Yang Z, Long F, Luo L, Yang B, Zhu R, et al. Long noncoding RNA MALAT1 mediates stem cell-like properties in human colorectal cancer cells by regulating miR-20b-5p/Oct4 axis. J Cell Physiol. (2019) 234:20816-28. doi: $10.1002 /$ jcp. 28687

150. Levine B, Kroemer G. Autophagy in the pathogenesis of disease. Cell. (2008) 132:27-42. doi: 10.1016/j.cell.2007.12.018

151. Mizushima N, Levine B, Cuervo AM, Klionsky DJ. Autophagy fights disease through cellular self-digestion. Nature. (2008) 451:1069-75. doi: 10.1038/nature06639

152. Maiuri MC, Zalckvar E, Kimchi A, Kroemer G. Self-eating and self-killing: crosstalk between autophagy and apoptosis. Nat Rev Mol Cell Biol. (2007) 8:741-52. doi: 10.1038/nrm2239

153. Mizushima N, Komatsu M. Autophagy: renovation of cells and tissues. Cell. (2011) 147:728-41. doi: 10.1016/j.cell.2011.10.026

154. Klionsky DJ. The molecular machinery of autophagy: unanswered questions. J Cell Sci. (2005) 118 (Pt 1):7-18. doi: 10.1242/jcs.01620

155. Yang L, Wang H, Shen Q, Feng L, Jin H. Long non-coding RNAs involved in autophagy regulation. Cell Death Dis. (2017) 8:e3073. doi: $10.1038 /$ cddis.2017.464

156. Devenish RJ, Prescott M. Autophagy: starvation relieves transcriptional repression of ATG genes. Curr Biol. (2015) 25:R238-R40. doi: 10.1016/j.cub.2015.01.045

157. Liu X, Xiao ZD, Han L, Zhang J, Lee SW, Wang W, et al. LncRNA NBR2 engages a metabolic checkpoint by regulating AMPK under energy stress. Nat Cell Biol. (2016) 18:431-42. doi: 10.1038/ncb3328

158. Zhuo C, Jiang R, Lin X, Shao M. LncRNA H19 inhibits autophagy by epigenetically silencing of DIRAS3 in diabetic cardiomyopathy. Oncotarget. (2017) 8:1429-37. doi: 10.18632/oncotarge t.13637

159. Tang S, Tan G, Jiang X, Han P, Zhai B, Dong X, et al. An artificial lncRNA targeting multiple miRNAs overcomes sorafenib resistance in hepatocellular carcinoma cells. Oncotarget. (2016) 7:73257-69. doi: 10.18632/oncotarget.12304

160. Pawar K, Hanisch C, Palma Vera SE, Einspanier R, Sharbati S. Down regulated lncRNA MEG3 eliminates mycobacteria in macrophages via autophagy. Sci Rep. (2016) 6:19416. doi: 10.1038/srep19416

161. Chen CL, Tseng YW, Wu JC, Chen GY, Lin KC, Hwang SM, et al. Suppression of hepatocellular carcinoma by baculovirus-mediated expression of long non-coding RNA PTENP1 and MicroRNA regulation. Biomaterials. (2015) 44:71-81. doi: 10.1016/j.biomaterials.2014.12.023

162. Chen ZH, Wang WT, Huang W, Fang K, Sun YM, Liu SR, et al. The lncRNA HOTAIRM1 regulates the degradation of PML-RARA oncoprotein and myeloid cell differentiation by enhancing the autophagy pathway. Cell Death Differ. (2017) 24:212-24. doi: 10.1038/cdd.2016.111

163. Wang Y, Hu Y, Sun C, Zhuo S, He Z, Wang H, et al. Down-regulation of Risa improves insulin sensitivity by enhancing autophagy. FASEB J. (2016) 30:3133-45. doi: 10.1096/fj.201500058R

164. Xiu Y-L, Sun K-X, Chen X, Chen S, Zhao Y, Guo Q-G, et al. Upregulation of the lncRNA Meg3 induces autophagy to inhibit tumorigenesis and progression of epithelial ovarian carcinoma by regulating activity of ATG3. Oncotarget. (2017) 8:31714-25. doi: 10.18632/oncotarget.15955

165. Chen Y-N, Cai M-Y, Xu S, Meng M, Ren X, Yang JW, et al. Identification of the lncRNA, AK156230, as a novel regulator of cellular senescence in mouse embryonic fibroblasts. Oncotarget. (2016) 7:52673-84. doi: 10.18632/oncotarget. 10170

166. Santana-Codina N, Mancias JD, Kimmelman AC. The role of autophagy in cancer. Ann Rev Cancer Biol. (2017) 1:19-39. doi: 10.1146/annurev-cancerbio-041816-122338

167. Kung CP, Budina A, Balaburski G, Bergenstock MK, Murphy M. Autophagy in tumor suppression and cancer therapy. Crit Rev Eukaryot Gene Expr. (2011) 21:71-100. doi: 10.1615/CritRevEukarGeneExpr.v21.i1.50

168. Avalos Y, Canales J, Bravo-Sagua R, Criollo A, Lavandero S, Quest AF. Tumor suppression and promotion by autophagy. Biomed Res Int. (2014) 2014:603980. doi: 10.1155/2014/603980

169. White E. The role for autophagy in cancer. J Clin Invest. (2015) 125:42-6. doi: 10.1172/JCI73941

170. Shan TD, Xu JH, Yu T, Li JY, Zhao LN, Ouyang H, et al. Knockdown of linc-POU3F3 suppresses the proliferation, apoptosis, and migration resistance of colorectal cancer. Oncotarget. (2016) 7:961-75. doi: 10.18632/oncotarget.5830

171. Zheng Y, Tan K, Huang H. Long noncoding RNA HAGLROS regulates apoptosis and autophagy in colorectal cancer cells via sponging miR100 to target ATG5 expression. J Cell Biochem. (2019) 120:3922-33. doi: $10.1002 /$ jcb. 27676

172. Bian Z, Jin L, Zhang J, Yin Y, Quan C, Hu Y, et al. LncRNA-UCA1 enhances cell proliferation and 5-fluorouracil resistance in colorectal cancer by inhibiting miR-204-5p. Sci Rep. (2016) 6:23892. doi: 10.1038/srep 23892

173. Li Y, Li C, Li D, Yang L, Jin J, Zhang B. IncRNA KCNQ1OT1 enhances the chemoresistance of oxaliplatin in colon cancer by targeting the miR-34a/ATG4B pathway. Oncotargets Ther. (2019) 12:2649-60. doi: $10.2147 / O T T . S 188054$

174. Hemelaar J, Lelyveld VS, Kessler BM, Ploegh HL. A single protease, Apg4B, is specific for the autophagy-related ubiquitin-like proteins GATE16, MAP1-LC3, GABARAP, and Apg8L. J Biol Chem. (2003) 278:51841-50. doi: 10.1074/jbc.M308762200

175. Raguz S, Yague E. Resistance to chemotherapy: new treatments and novel insights into an old problem. Br J Cancer. (2008) 99:387-91. doi: $10.1038 /$ sj.bjc. 6604510

176. Tan DSW, Gerlinger M, Teh B-T, Swanton C. Anti-cancer drug resistance: understanding the mechanisms through the use of integrative genomics and functional RNA interference. Eur J Cancer. (2010) 46:2166-77. doi: 10.1016/j.ejca.2010.03.019

177. Senthebane DA, Rowe A, Thomford NE, Shipanga H, Munro D, Mazeedi MAMA, et al. The role of tumor microenvironment in chemoresistance: 
to survive, keep your enemies closer. Int J Mol Sci. (2017) 18:1586. doi: 10.3390/ijms18071586

178. Marshall JL, Haller DG, de Gramont A, Hochster HS, Lenz H-J, Ajani JA, et al. Adjuvant therapy for stage II and III colon cancer: consensus report of the International Society of Gastrointestinal Oncology. Gastrointest Cancer Res. (2007) 1:146-54.

179. Moertel CG, Fleming TR, Macdonald JS, Haller DG, Laurie JA, Tangen $\mathrm{CM}$, et al. Intergroup study of fluorouracil plus levamisole as adjuvant therapy for stage II/Dukes' B2 colon cancer. J Clin Oncol. (1995) 13:2936-43. doi: 10.1200/JCO.1995.13.12.2936

180. Gill S, Loprinzi CL, Sargent DJ, Thome SD, Alberts SR, Haller DG, et al. Pooled analysis of fluorouracil-based adjuvant therapy for stage II and III colon cancer: who benefits and by how much? J Clin Oncol. (2004) 22:1797-806. doi: 10.1200/JCO.2004.09.059

181. Martini G, Troiani T, Cardone C, Vitiello P, Sforza V, Ciardiello D, et al. Present and future of metastatic colorectal cancer treatment: a review of new candidate targets. World J Gastroenterol. (2017) 23:4675-88. doi: 10.3748 /wjg.v23.i26.4675

182. Hurwitz H, Fehrenbacher L, Novotny W, Cartwright T, Hainsworth J, Heim W, et al. Bevacizumab plus irinotecan, fluorouracil, and leucovorin for metastatic colorectal cancer. N Engl J Med. (2004) 350:2335-42. doi: 10.1056/NEJMoa032691

183. Cunningham D, Humblet Y, Siena S, Khayat D, Bleiberg H, Santoro A, et al. Cetuximab monotherapy and cetuximab plus irinotecan in irinotecanrefractory metastatic colorectal cancer. N Engl J Med. (2004) 351:337-45. doi: 10.1056/NEJMoa033025

184. Van Cutsem E, Peeters M, Siena S, Humblet Y, Hendlisz A, Neyns B, et al. Open-label phase III trial of panitumumab plus best supportive care compared with best supportive care alone in patients with chemotherapyrefractory metastatic colorectal cancer. J Clin Oncol. (2007) 25:1658-64. doi: 10.1200/JCO.2006.08.1620

185. Tabernero J, Yoshino T, Cohn AL, Obermannova R, Bodoky G, GarciaCarbonero R, et al. Ramucirumab versus placebo in combination with second-line FOLFIRI in patients with metastatic colorectal carcinoma that progressed during or after first-line therapy with bevacizumab, oxaliplatin, and a fluoropyrimidine (RAISE): a randomised, doubleblind, multicentre, phase 3 study. Lancet Oncol. (2015) 16:499-508. doi: 10.1016/S1470-2045(15)70127-0

186. Peeters M, Price TJ, Cervantes A, Sobrero AF, Ducreux M, Hotko Y, et al. Randomized phase III study of panitumumab with fluorouracil, leucovorin, and irinotecan (FOLFIRI) compared with FOLFIRI alone as second-line treatment in patients with metastatic colorectal cancer. J Clin Oncol. (2010) 28:4706-13. doi: 10.1200/JCO.2009.27.6055

187. Corrà F, Agnoletto C, Minotti L, Baldassari F, Volinia S. The network of non-coding RNAs in cancer drug resistance. Front Oncol. (2018) 8:1-25. doi: $10.3389 /$ fonc. 2018.00327

188. Jiang X, Li Q, Zhang S, Song C, Zheng P. Long noncoding RNA GIHCG induces cancer progression and chemoresistance and indicates poor prognosis in colorectal cancer. Oncotargets Ther. (2019) 12:1059-70. doi: 10.2147/OTT.S192290

189. Lu Y, Zhao X, Liu Q, Li C, Graves-Deal R, Cao Z, et al. LncRNA MIR100HGderived miR-100 and miR-125b mediate cetuximab resistance via Wnt/ $\beta$ catenin signaling. Nat Med. (2017) 23:1331-41. doi: 10.1038/nm.4424

190. Yang Y-n, Zhang R, Du J-w, Yuan H-h, Li Y-j, Wei X-l, et al. Predictive role of UCA1-containing exosomes in cetuximab-resistant colorectal cancer. Cancer Cell Int. (2018) 18:1-11. doi: 10.1186/s12935-018-0660-6

191. Bian Z, Zhang J, Li M, Feng Y, Yao S, Song M, et al. Long non-coding RNA LINC00152 promotes cell proliferation, metastasis, and confers 5-FU resistance in colorectal cancer by inhibiting miR-139-5p. Oncogenesis. (2017) 6:395. doi: 10.1038/s41389-017-0008-4

192. Yue B, Cai D, Liu C, Fang C, Yan D. Linc00152 functions as a competing endogenous RNA to confer oxaliplatin resistance and holds prognostic values in colon cancer. Am Soc Gene Cell Ther. (2016) 24:2064-77. doi: $10.1038 / \mathrm{mt} .2016 .180$

193. Qiao L, Liu X, Tang Y, Zhao Z, Zhang J. Knockdown of long non-coding RNA prostate cancer-associated ncRNA transcript 1 inhibits multidrug resistance and c-Myc- dependent aggressiveness in colorectal cancer Caco-2 and HT-29 cells. Mol Cell Biochem. (2018) 441:99-108. doi: 10.1007/s11010-017-3177-8

194. Fan H, Zhu JHUA, Yao XUEQ. Knockdown of long non-coding RNA PVT1 reverses multidrug resistance in colorectal cancer cells. Mol Med Rep. (2018) 17:8309-15. doi: 10.3892/mmr.2018.8907

195. Zhu J, Zhang R, Yang D, Li J, Yan X, Jin K, et al. Knockdown of long noncoding RNA XIST inhibited doxorubicin resistance in colorectal cancer by upregulation of miR-124 and downregulation of SGK1. Cell Physiol Biochem. (2018) 51:113-28. doi: 10.1159/000495168

196. Tang D, Yang Z, Long F, Luo L, Yang B, Zhu R, et al. Inhibition of MALAT1 reduces tumor growth and metastasis and promotes drug sensitivity in colorectal cancer. Cell Signal. (2019) 57:21-8. doi: 10.1016/j.cellsig.2019.01.013

197. Li P, Zhang X, Wang H, Wang L, Liu T, Du L, et al. MALAT1 is associated with poor response to oxaliplatin-based chemotherapy in colorectal cancer patients and promotes chemoresistance through EZH2. Mol Cancer Ther. (2017) 16:739-52. doi: 10.1158/1535-7163.MCT-16-0591

198. Li Y, Huang S, Li Y, Zhang W, He K, Zhao M, et al. Decreased expression of LncRNA SLC25A25-AS1 promotes proliferation, chemoresistance, and EMT in colorectal cancer cells. Tumor Biol. (2016) 37:14205-15. doi: 10.1007/s13277-016-5254-0

199. Lee H, Kim C, Ku J-l, Kim W, Yoon SK, Kuh H-j, et al. A long non-coding RNA snaR contributes to 5-fluorouracil resistance in human colon cancer cells. Mol Cells. (2014) 37:540-6. doi: 10.14348/molcells.2014.0151

200. Li J, Li X, Cen C, Ai X, Lin C, Hu G. The long non-coding RNA ENST00000547547 reduces 5-fluorouracil resistance of colorectal cancer cells via competitive binding to microRNA-31. Oncol Rep. (2018) 39:217-26. doi: 10.3892/or.2017.6082

201. Li C, Gao Y, Li Y, Ding D. TUG1 mediates methotrexate resistance in colorectal cancer via miR-186/CPEB2 axis. Biochem Biophys Res Commun. (2017) 491:552-7. doi: 10.1016/j.bbrc.2017.03.042

202. Ping G, Xiong $\mathrm{W}$, Zhang L, Li Y, Zhang Y, Zhao Y. Silencing long noncoding RNA PVT1 inhibits tumorigenesis and cisplatin resistance of colorectal cancer. Am J Transl Res. (2018) 10:138-49.

203. Wang H, Li H, Zhang L, Yang D. Overexpression of MEG3 sensitizes colorectal cancer cells to oxaliplatin through regulation of miR-141/PDCD4 axis. Biomed Pharmacother. (2018) 106:1607-15. doi: 10.1016/j.biopha.2018.07.131

204. Li L, Jian S, Yupeng Z, Liu S, Yanan P, Zhou Z, et al. MEG3 is a prognostic factor for CRC and promotes chemosensitivity by enhancing oxaliplatin-induced cell apoptosis. Oncol Rep. (2017) 38:1383-92. doi: 10.3892/or.2017.5828

Conflict of Interest: The authors declare that the research was conducted in the absence of any commercial or financial relationships that could be construed as a potential conflict of interest.

The reviewer NJ-H declared a past co-authorship with one of the authors, CL-C, to the handling editor.

Copyright (c) 2019 Bermúdez, Aguilar-Medina, Lizárraga-Verdugo, Avendaño-Félix, Silva-Benitez, López-Camarillo and Ramos-Payán. This is an open-access article distributed under the terms of the Creative Commons Attribution License (CC BY). The use, distribution or reproduction in other forums is permitted, provided the original author(s) and the copyright owner(s) are credited and that the original publication in this journal is cited, in accordance with accepted academic practice. No use, distribution or reproduction is permitted which does not comply with these terms. 